\title{
Future methane, hydroxyl, and their uncertainties: key climate and emission parameters for future predictions
}

\author{
C. D. Holmes ${ }^{1}$, M. J. Prather ${ }^{1}$, O. A. Søvde ${ }^{2}$, and G. Myhre ${ }^{2}$ \\ ${ }^{1}$ Department of Earth System Science, University of California, Irvine, CA 92697-3100, USA \\ ${ }^{2}$ Center for International Climate and Environmental Research (CICERO), Oslo, Norway
}

Correspondence to: C. D. Holmes (cdholmes@uci.edu)

Received: 1 August 2012 - Published in Atmos. Chem. Phys. Discuss.: 20 August 2012

Revised: 31 December 2012 - Accepted: 2 January 2013 - Published: 11 January 2013

\begin{abstract}
Accurate prediction of future methane abundances following a climate scenario requires understanding the lifetime changes driven by anthropogenic emissions, meteorological factors, and chemistry-climate feedbacks. Uncertainty in any of these influences or the underlying processes implies uncertainty in future abundance and radiative forcing. We simulate methane lifetime in three chemical transport models (CTMs) - UCI CTM, GEOS-Chem, and Oslo CTM3 - over the period 1997-2009 and compare the models' year-to-year variability against constraints from global methyl chloroform observations. Using sensitivity tests, we find that temperature, water vapor, stratospheric ozone column, biomass burning and lightning $\mathrm{NO}_{\mathrm{x}}$ are the dominant sources of interannual changes in methane lifetime in all three models. We also evaluate each model's response to forcings that have impacts on decadal time scales, such as methane feedback, and anthropogenic emissions. In general, these different CTMs show similar sensitivities to the driving variables. We construct a parametric model that reproduces most of the interannual variability of each CTM and use it to predict methane lifetime from 1980 through 2100 following a specified emissions and climate scenario (RCP 8.5). The parametric model propagates uncertainties through all steps and provides a foundation for predicting methane abundances in any climate scenario. Our sensitivity tests also enable a new estimate of the methane global warming potential (GWP), accounting for stratospheric ozone effects, including those mediated by water vapor. We estimate the 100-yr GWP to be 32 , which is $25 \%$ larger than past assessments.
\end{abstract}

\section{Introduction}

Rising atmospheric concentrations of greenhouse gases are the main cause of current and future climate change (Intergovernmental Panel on Climate Change, hereafter IPCC, 2007). Uncertainty in mapping an emission scenario onto future abundance of greenhouse gases (GHGs) thus translates almost directly into uncertainty in our ability to project climate change and its impact on nature and society. To date, IPCC has generally adopted a single trajectory for the growth of greenhouse gases in each of several different socioeconomic scenarios, thus neglecting uncertainty in those future abundances. For methane, the second most important anthropogenic GHG, these trajectories are based on simple parametric formulas for methane lifetime. In the IPCC Third Assessment Report (TAR), 4 parameters accounted for changes in the largest atmospheric methane sink, oxidation by tropospheric $\mathrm{OH}$ : anthropogenic emissions of $\mathrm{CO}$, nitrogen oxides $\left(\mathrm{NO}_{\mathrm{x}}\right)$, and volatile organic compounds (VOCs) and the negative feedback between methane abundance and tropospheric OH (Prather et al., 2001). Other sinks, which include oxidation in the stratosphere, oxidation by tropospheric chlorine, and uptake into soil, were assessed but assumed not to change during the 21 st century projections. For the upcoming IPCC 5th Assessment Report (AR5) the Representative Concentration Pathway (RCP) scenarios adopt methane trajectories calculated in the MAGICC model, which augments the TAR parametric formula with a temperature term (Meinshausen et al., 2011a).

On small spatial scales, $\mathrm{OH}$ concentrations and methane oxidation depend on temperature, pressure, sun elevation, clouds, surface albedo, UV attenuation by stratospheric 
ozone, and local concentrations of water vapor, ozone, $\mathrm{CH}_{4}, \mathrm{CO}, \mathrm{NO}_{\mathrm{x}}, \mathrm{VOCs}$, and aerosols (e.g. Duncan et al., 2000; Olson et al., 2006). Integrated globally and annually, some of these influences are small, but numerous studies have found that temperature, circulation, water vapor, stratospheric ozone, clouds and natural and anthropogenic emissions are important (Lelieveld and Crutzen, 1994; Spivakovsky et al., 2000; Dentener et al., 2003; Stevenson et al., 2005; Dalsoren et al., 2006; Fiore et al., 2006; Hess and Mahowald, 2009; Voulgarakis et al., 2010). Uncertainties in these factors and in the present-day methane budget mean that each socioeconomic emission scenario could produce a range of future methane abundances (Prather et al., 2012).

Global climate model (GCM) simulations with atmospheric chemistry provide another method for predicting future methane and other chemically reactive GHGs. An ensemble of such models can provide a range of future methane abundances for a single scenario (e.g. Atmospheric Chemistry and Climate Model Intercomparison Project (ACCMIP) Lamarque et al., 2012), spanning some, but likely not all, future uncertainties. This approach is computationally expensive, however, which restricts the number of socioeconomic scenarios and ensemble members that can be explored.

In this work we develop a new parametric model for global methane lifetime that accounts for climate-chemistry interactions that were neglected in previous parametric approaches. We derive the parametric factors from perturbation tests in a suite of 3 chemical transport models (CTMs), since CTMs with detailed tropospheric chemistry provide the best mechanistic representation of methane loss from tropospheric $\mathrm{OH}$. We focus on the tropospheric $\mathrm{OH}$ sink because other methane sinks are smaller and their intrinsic variability has a smaller impact on the total methane lifetime. The parametric model includes climate and emission factors that control the interannual variability of methane lifetime in the CTMs. These factors are likely important on decadal time scales as well. The parametric model also includes anthropogenic emissions that can drive decadal trends in methane lifetime, but contribute little to interannual variability. Uncertainties in atmospheric chemistry are included in the parametric factors based on the range of perturbation responses across the CTMs. We evaluate the parametric model against 13-yr CTM simulations of methane lifetime, and against observed variability in tropospheric $\mathrm{OH}$, as measured by the decay of methyl chloroform. Assuming that the same climate and emission processes will remain dominant drivers of methane lifetime throughout the 21 st century, we use this parametric model to make new projections of methane abundance and its uncertainty through 2100. Finally, the perturbation tests also enable a new estimate of the ozone contribution to methane radiative forcing and global warming potential.

\section{Model descriptions}

We diagnose methane lifetime due to tropospheric $\mathrm{OH}$, $\tau_{\mathrm{CH}_{4} \times \mathrm{OH}}$, from multi-year simulations in 3 different CTMs: University of Oslo CTM3, University of California, Irvine (UCI) CTM, and GEOS-Chem. All of these models are driven by assimilated meteorological data and configured to use the same emissions from anthropogenic, biogenic and biomass burning sources. We use year-specific meteorology spanning 1997-2009 for each model, except GEOSChem simulations with GEOS-5 meteorology, which are only 2004-2009. Sections 2.1-2.3 and Table S1 summarize features of each model and Sect. 2.4 describes the emissions.

Monthly chemistry diagnostics from each model enable us to calculate $\tau_{\mathrm{CH}_{4} \times \mathrm{OH}}$, defined as the total atmospheric $\mathrm{CH}_{4}$ burden divided by its loss through reactions with tropospheric $\mathrm{OH}$. All 3 models use fixed methane abundances (1760 ppb for UCI CTM and Oslo CTM3, $1775 \mathrm{ppb}$ for GEOS-Chem), so variations in $\tau_{\mathrm{CH}_{4} \times \mathrm{OH}}$ are due solely to changes in the $\mathrm{OH}$ sink. Different tropopause definitions in the models have minimal effect on $\tau_{\mathrm{CH}_{4} \times \mathrm{OH}}$ since $\mathrm{CH}_{4}$ oxidation between $200 \mathrm{hPa}$ and the tropopause is $1.5 \%$ of tropospheric methane loss, or less. We calculate the total methane lifetime, $\tau_{\mathrm{CH}_{4}}$, using $\tau_{\mathrm{CH}_{4} \times \mathrm{OH}}$ values from this work and recently estimated lifetimes for other methane sinks: tropospheric chlorine $(200 \mathrm{yr})$, stratosphere $(120 \mathrm{yr})$, and soil (150 yr) (Prather et al., 2012).

\subsection{Oslo CTM3}

Oslo CTM3 is a stratospheric and tropospheric CTM, recently described by Søvde et al. (2012). Transport is driven by pieced-forecast meteorology from the European Center for Medium-range Weather Forecasting (ECMWF) Integrated Forecast System (cycle 36r1, http://www.ecmwf. int/research/ifsdocs/CY36r1/index.html). The original T359 $\left(\sim 0.55^{\circ} \times 0.55^{\circ}\right)$ horizontal resolution and 60 layer vertical resolution of the forecast model is degraded to T42 $\left(\sim 2.8^{\circ} \times 2.8^{\circ}\right)$ resolution, while preserving the $3 \mathrm{~h}$ temporal resolution for all meteorological fields. Advection uses the second-order moments scheme (Prather, 1986; Prather et al., 2008) and convection follows Tiedtke (1989).

The Oslo CTM3 chemical mechanism includes a full stratospheric chemical mechanism in addition to tropospheric reactions. The tropospheric module contains 105 reactions and 51 gas-phase species, including sulfate, nitrate, and sea-salt aerosols. Nitrate aerosols influence gas-phase chemistry through $\mathrm{HNO}_{3}$ uptake, which is a sink for reactive nitrogen through subsequent wet scavenging. Photolysis rates required in the chemistry mechanism are calculated online using the Fast-JX method (Neu et al., 2007), with cloud distributions from ECMWF meteorology and ozone concentrations calculated in the CTM. Aerosol effects on photolysis are neglected except for a small contribution from black carbon (Søvde et al., 2012), which increases OH and biases 
Table 1. Emissions.

\begin{tabular}{llll}
\hline Source (Inventory) $^{\mathrm{a}}$ & $\mathrm{NO}_{\mathrm{x}}, \mathrm{Tg}(\mathrm{N}) \mathrm{yr}^{-1}$ & $\mathrm{CO}, \mathrm{Tg} \mathrm{yr}^{-1}$ & ${\text { Isoprene, } \mathrm{Tg} \mathrm{yr}^{-1}}$ \\
\hline Anthropogenic (RCP year 2000) & $32^{\mathrm{b}}$ & 609 & - \\
Biomass burning (GFED3) & $5.6^{\mathrm{c}}$ & $360^{\mathrm{c}}$ & - \\
Biogenic (MEGAN) & - & 76 & 523 \\
Lightning & $5^{\mathrm{d}}$ & - & - \\
\hline Total & 42 & 1047 & 523 \\
\hline
\end{tabular}

${ }^{a}$ Inventory references: RCP, Lamarque et al. (2010); van Vuuren et al. (2011), GFED3 (van der Werf et al. (2010),

MEGAN Guenther et al. (2006).

${ }^{b}$ Land, ship, and aviation components are $26,5.4$, and $0.85 \mathrm{Tg}(\mathrm{N}) \mathrm{yr}^{-1}$, respectively.

${ }^{c}$ Average biomass burning for 1997-2009. Emissions for individual years are 3.3-6.1 $\mathrm{Tg}(\mathrm{N}) \mathrm{yr}^{-1}$ and

$263-605 \mathrm{Tg}(\mathrm{CO}) \mathrm{yr}^{-1}$.

${ }^{d}$ Average for 1997-2009 in UCI CTM and Oslo CTM3. Emissions for individual years are 4.8-5.4 $\mathrm{Tg}(\mathrm{N}) \mathrm{yr}^{-1}$.

GEOS-Chem has 5.7-6.4 $\mathrm{Tg}(\mathrm{N}) \mathrm{yr}^{-1}$ (average $6 \mathrm{Tg}(\mathrm{N}) \mathrm{yr}^{-1}$ ) over 2004-2009.

$\tau_{\mathrm{CH}_{4} \times \mathrm{OH}}$ low by about $10 \%$ (Bian et al., 2003; Martin et al., 2003). Oslo CTM3 shares the same chemical mechanism and some other physical process algorithms with the older Oslo CTM2, which has been extensively used for studies of present and future tropospheric composition (Isaksen et al., 2005; Hoor et al., 2009; Dalsoren et al., 2010).

\subsection{UCI CTM}

The UCI CTM is a tropospheric CTM, using the same meteorology, transport algorithms, and Fast-JX photolysis as Oslo CTM3. Like Oslo CTM3, the UCI CTM uses T42 horizontal resolution, but the vertical resolution in the boundary layer is reduced, so there are 57 layers total. Tropospheric chemistry of the major gas-phase species involved in $\mathrm{HO}_{\mathrm{x}}, \mathrm{NO}_{\mathrm{x}}$, $\mathrm{O}_{3}$, and VOC reactions is simulated with the ASAD package (Carver et al., 1997), with updates to the mechanism and kinetics (Tang and Prather, 2010). This mechanism includes 84 reactions involving 33 species, making it simpler than the Oslo CTM3 chemical mechanism. As in Oslo CTM3, clouds from ECMWF meteorology are used for photolysis. Simplified stratospheric $\mathrm{O}_{3}$ chemistry is simulated with Linoz (version 2, Hsu and Prather, 2009) and used for photolysis calculations and stratosphere-troposphere exchange. Aerosol effects on chemistry are neglected, which biases $\tau_{\mathrm{CH}_{4} \times \mathrm{OH}}$ low by up to $5 \%$ in addition to the aerosol-induced photolysis bias described above for Oslo CTM3 (Martin et al., 2003; Macintyre and Evans, 2010).

\subsection{GEOS-Chem}

GEOS-Chem is a tropospheric CTM, driven by assimilated meteorological data from the NASA Goddard Earth Observing System (GEOS-5) or MERRA reanalysis (Rienecker et al., 2008, 2011). Both GEOS-5 and MERRA are produced from closely related assimilation systems, using the same spatial resolution of $0.5^{\circ} \times 0.66^{\circ}$ and 72 vertical layers. We use GEOS-Chem version 9-01-02 here. Most results, including all sensitivity simulations, are based on GEOS-5 meteo- rology, which has been degraded to $2^{\circ} \times 2.5^{\circ}$ and 47 layers for the CTM. GEOS-5 data are available only after 2004, however, so we also simulate 1997-2009 using MERRA meteorology at $4^{\circ} \times 5^{\circ}$ and 47 layers. Temporal resolution in GEOS-5 (MERRA) is $6 \mathrm{~h}(3 \mathrm{~h})$ for most meteorological quantities and $3 \mathrm{~h}(1 \mathrm{~h})$ for surface quantities and mixing depth.

The tropospheric chemistry mechanism in GEOS-Chem, as recently updated by Mao et al. (2010), consists of 104 species and 236 chemical reactions that simulate aerosols in addition to the $\mathrm{HO}_{\mathrm{x}}-\mathrm{NO}_{\mathrm{x}}-\mathrm{VOC}$-ozone system. Photolysis rates are calculated with the Fast-JX method, using aerosol optical depths that are simulated internally, and ozone columns from the TOMS and SBUV satellites (until 2008) or GEOS-5 assimilation of satellite data (after 2008). For purposes of stratosphere-troposphere exchange, stratospheric ozone is simulated with Linoz.

\subsection{Emissions}

Emissions used in this work are representative of 1997-2010, but do not resolve trends or interannual variability in anthropogenic or biogenic emissions. To the extent possible, we use identical emissions across all models. Anthropogenic, biogenic, and biomass burning emissions of $\mathrm{NO}_{\mathrm{x}}, \mathrm{CO}$, and isoprene are fully consistent in all models. Some differences in VOC emissions arise because of the different lumping schemes used in the various chemical mechanisms and because some VOC species are not simulated in all models. Lightning $\mathrm{NO}_{\mathrm{x}}$ emissions also differ between models because they are calculated from underlying meteorology, as described below.

Table 1 summarizes emissions of key species. We use the RCP inventory for anthropogenic emissions for year 2000, repeating in each simulated year (Lamarque et al., 2010; van Vuuren et al., 2011). This inventory provides monthly gridded emissions of $\mathrm{NO}_{\mathrm{x}}, \mathrm{CO}$ and speciated VOCs from 11 emission activities. Aviation and shipping emissions change each month, while other anthropogenic emissions are 
constant throughout the year. Biomass burning emissions are specified for each year and month by the GFED inventory (version 3, van der Werf et al., 2010). We use this instead of the climatological biomass burning emissions provided in the RCP inventory because fires are a major cause of yearto-year variability in tropospheric OH (Duncan et al., 2003; Manning et al., 2005; Dalsoren et al., 2006). Biogenic emissions of isoprene, $\mathrm{CO}$, and other VOCs are from a MEGAN climatology for the 2000s decade (Guenther et al., 2006). Anthropogenic, biogenic, and biomass burning emission data are provided at $0.5^{\circ} \times 0.5^{\circ}$ resolution. GEOS-Chem includes additional oceanic emissions of acetone $\left(13 \mathrm{Tg} \mathrm{yr}^{-1}\right.$, Jacob et al., 2002) and acetaldehyde (57 $\mathrm{Tg} \mathrm{yr}^{-1}$, Millet et al., 2010), which are not included in other models. All emissions except aviation, biomass burning and lightning occur in the lowest model layer and are quickly mixed vertically through boundary layer convection and turbulence. Biomass burning is assumed to occur at the surface in the UCI CTM and GEOSChem. In Oslo CTM3, however, biomass burning emissions follow the RETRO vertical distribution (Schultz et al., 2008), which injects $35 \%$ of equatorial emissions and $45 \%$ of boreal emissions above the boundary layer. In a sensitivity test we inject all biomass burning into the lowest model layer in Oslo CTM3.

Lightning $\mathrm{NO}_{\mathrm{x}}$ emissions are calculated with similar methods in all 3 CTMs, with UCI CTM and Oslo CTM3 using identical algorithms. In all models, these emissions are derived from cloud-top heights in the underlying meteorology (Price and Rind, 1994) and scaled to match satelliteobserved lightning flash rates (Christian et al., 2003). In the UCI CTM and Oslo CTM3, 2 scale factors are calculated to match observed multi-year mean flash rates over land and ocean. In GEOS-Chem scale factors are calculated for every grid column and month (Sauvage et al., 2007). Within the convective column, lightning $\mathrm{NO}_{\mathrm{x}}$ is distributed vertically based on $\mathrm{NO}_{\mathrm{x}}$ observations near thunderstorms (Ott et al., 2010). Søvde et al. (2012) provide a full description of lightning emissions in UCI CTM and Oslo CTM3, and Murray et al. (2012) do the same for GEOS-Chem. Lightning $\mathrm{NO}_{\mathrm{x}}$ emissions average $6 \mathrm{Tg}(\mathrm{N}) \mathrm{yr}^{-1}$ in GEOS-Chem and $5 \mathrm{Tg}(\mathrm{N}) \mathrm{yr}^{-1}$ in UCI CTM and Oslo CTM3.

\section{Recent (1997-2009) variability of $\mathrm{CH}_{4}$ lifetime}

Figure 1 shows $\tau_{\mathrm{CH}_{4} \times \mathrm{OH}}$ for $1997-2009$, as simulated by the $3 \mathrm{CTMs}$. The tropospheric $\mathrm{OH}$ lifetimes range from 8.5 to $10.1 \mathrm{yr}$. The longest of these lifetimes (GEOS-Chem) is consistent with the constraint provided by methyl chloroform observations, 11.2 $\pm 1.3 \mathrm{yr}$ (Prather et al., 2012), but all are within the range of contemporary tropospheric chemistry models (e.g. $9.7 \pm 1.5 \mathrm{yr}$ from ACCMIP, Naik et al., 2012).

These simulations show similar variability of $\tau_{\mathrm{CH}_{4} \times \mathrm{OH}}$ in all CTMs. Common features include a sharp dip in 1998 and peak in 2000, coincident with a strong El Niño and

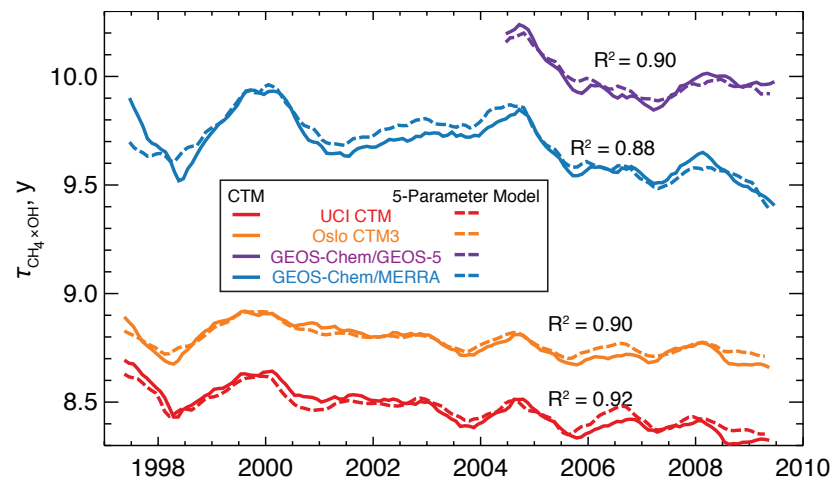

Fig. 1. Methane lifetime due to oxidation by tropospheric $\mathrm{OH}$ $\left(\tau_{\mathrm{CH}_{4}} \times \mathrm{OH}\right)$ simulated by each CTM (solid lines) and reconstructed from the 5-parameter model (dashed lines). The parameters are air temperature, water vapor, ozone column, lightning $\mathrm{NO}_{\mathrm{x}}$ emission, and biomass burning emission. Parameter values for each CTM are given in Table 2 and the corresponding variables are in Fig. 3. $R^{2}$ values show correlation between each CTM and its own 5parameter model. GEOS-Chem simulations use either MERRA or GEOS-5 meteorology. All lifetimes are smoothed with a 12-month running mean.

La Niña, smaller peaks in 2004 and 2008, and general decline after 2005. These features appear robust against the various choices of chemical mechanism, meteorology, and resolution used in these CTMs. In independent work, the ECHAM model also simulates the same features, using different chemistry and emissions that include biogenic variations (Montzka et al., 2011). Oslo CTM3 has the least variability $(0.65 \%$ for $\sigma /$ mean $)$, while GEOS-Chem with MERRA meteorology has the most $(1.1 \%)$. The common features, as well as differences in their magnitude, are explained below by a small number of processes (Sect. 3.3).

\subsection{Methyl chloroform comparison}

Two global measurement networks have recorded the growth and decline of atmospheric methyl chloroform (MCF) since the 1970s (ALE/GAGE/AGAGE, Prinn et al., 2005), with expanded coverage since the 1990s (NOAA, Montzka et al., 2000). Like methane, atmospheric MCF is oxidized mainly by tropospheric $\mathrm{OH}$, with small additional sinks in the stratosphere, oceans, and soil (Volk et al., 1997; Wennberg et al., 2004; Wang et al., 2008). Because MCF has no natural sources and the anthropogenic production is well known (McCulloch et al., 1999), MCF provides the best available constraint on global $\mathrm{OH}$ levels and methane lifetime. The analysis here uses observations since 1998, when anthropogenic MCF emissions became small compared to atmospheric oxidation of the residual atmospheric burden. Consequently, MCF atmospheric lifetimes can be inferred from observed decay rates without detailed accounting for emissions and transport (Montzka et al., 2011). 


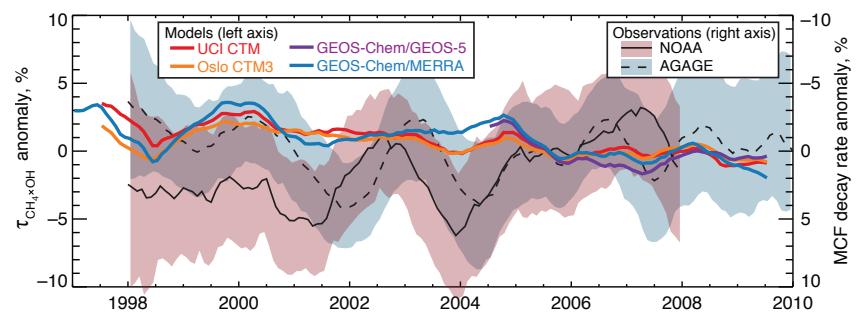

Fig. 2. Interannual variability of $\tau_{\mathrm{CH}_{4}} \times \mathrm{OH}$ in CTMs and observed global-mean methyl chloroform (MCF) decay rate. Observations are derived from atmospheric MCF abundances at NOAA and AGAGE surface stations (Montzka et al., 2000; Prinn et al., 2005), with an uncertainty (shaded) given by the 16th to 84th percentile range $( \pm 1 \sigma)$ of decay rates across stations within each network, and adjusted by the tropospheric $\mathrm{OH}$ fraction of total MCF loss. All data are shown as anomalies relative to their own 2004-2010 mean (2004-2008 for NOAA data). Models, observations, and uncertainties are smoothed with a 12-month running average. Note anomalies in $\tau_{\mathrm{CH}_{4} \times \mathrm{OH}}$ and decay rate have opposite sign.

For each network, we calculate decay rates of MCF from monthly average concentrations provided by each network (NOAA: ftp://ftp.cmdl.noaa.gov/hats/solvents/ CH3CCl3/flasks/GCMS/CH3CCL3_GCMS_flask.txt, last access: 6 August 2012; AGAGE: http://agage.eas.gatech. edu/data_archive/agage/gc-md/monthly/, last access: 4 April 2012). For site $i$ and month $t$ the observed decay rate $\left(\mathrm{yr}^{-1}\right)$ is

$k_{i, t}=-\ln \left(c_{i,(t+6)} / c_{i,(t-6)}\right)$,

where $c_{i, t}$ is the concentration at site $i$ in month $t$. The global MCF decay rate is the average of $k_{i, t}$ across sites within a network. We calculate uncertainty in the global decay rate as the 16 th- 84 th percentile range (i.e. $\pm 1 \sigma$ ) of $k_{i, t}$ across sites within a network. No filling is used for months with missing data. (See Supplement for additional method details.) Averaged over 1998-2007, the global MCF decay rates from the 2 networks differ by less than $1 \%\left(0.1811 \mathrm{yr}^{-1}\right.$ for NOAA, $0.1796 \mathrm{yr}^{-1}$ for AGAGE), providing a strong constraint on the long-term global-mean $\mathrm{OH}$ and methane lifetime. This analysis, however, focuses on anomalies in the global decay rate, relative to each network's own mean. Because the anomalies are attributed solely to tropospheric $\mathrm{OH}$ loss (see below) and for comparison to $\tau_{\mathrm{CH}_{4} \times \mathrm{OH}}$, the decay anomalies are divided by $r=0.87$ to account for the tropospheric $\mathrm{OH}$ fraction of total MCF loss (Prather et al., 2012).

Figure 2 compares the interannual variability of simulated $\tau_{\mathrm{CH}_{4} \times \mathrm{OH}}$ in the CTMs against the MCF decay rate. In all CTMs, simulated $\tau_{\mathrm{CH}_{4} \times \mathrm{OH}}$ variations $(0.7-1.1 \%$ for $\sigma /$ mean) are smaller than the upper limit imposed by the MCF constraint (2.3\%, Montzka et al., 2011). Adding variable isoprene emissions to the GEOS-Chem simulation increases the simulated variability by only $0.1 \%$ (not shown). While the CTM $\tau_{\mathrm{CH}_{4} \times \mathrm{OH}}$ anomalies are consistently within the observational uncertainty for both the AGAGE and NOAA networks (shaded region of Fig. 2), the year-toyear changes in the models generally do not correlate with the MCF data. Residual anthropogenic or ocean emissions could account for some MCF decay anomalies, but only if these emissions change abruptly from year to year. Emission anomalies of about $4 \mathrm{Gg} \mathrm{yr}^{-1}$ would be required to cause the observed decay rate swings during 2002-2004. Meanwhile, total anthropogenic and ocean emissions for those years are estimated to be 6 and $4 \mathrm{Gg} \mathrm{yr}^{-1}$, respectively, and decreasing smoothly (Wennberg et al., 2004; Prinn et al., 2005; Montzka et al., 2011). Therefore, abrupt emission changes might explain part, perhaps half, of the decay anomalies, but cannot account for the full discrepancy between simulated $\tau_{\mathrm{CH}_{4} \times \mathrm{OH}}$ and observations.

Collocated measurement sites in the NOAA and AGAGE networks provide an alternative means to evaluate possible errors in decay rates. With MCF concentrations about $30 \mathrm{ppt}$ $\left(1 \mathrm{ppt}=1 \mathrm{pmol} \mathrm{mol}^{-1}\right)$ in 2003 and decaying at a rate of $6 \mathrm{pptyr}^{-1}$, quantifying $\tau_{\mathrm{CH}_{4} \times \mathrm{OH}}$ anomalies of $1 \%$ requires measurement accuracy of $0.06 \mathrm{ppt}$ or better for the monthly mean concentration. At all 4 collocated sites (Cape Grim, American Samoa, Trinidad Head, and Mace Head) we find differences between the networks as large as $2 \%(\sim 0.1$ to $0.5 \mathrm{pmol} \mathrm{mol}^{-1}$ ) in the monthly means. (See Fig. S2) While small in absolute terms, these differences exceed the standard error in monthly means and persist for several consecutive months; thus they are likely not caused by synoptic variability and differences in sampling frequency. Because the biases change over time, they lead to differences of up to $4 \%$ in MCF decay rates at a single site. As can be seen in Fig. 2, both networks find similar magnitude of $\mathrm{OH}$ variability, but they differ in sign and magnitude of the anomaly at many times. These differences in observed MCF decay rates between the two networks are as large as the discrepancy between CTM $\tau_{\mathrm{CH}_{4} \times \mathrm{OH}}$ anomalies and either set of observations. Therefore, we conclude that better understanding of systematic differences between the observation networks is required before MCF can be used to constrain $\tau_{\mathrm{CH}_{4} \times \mathrm{OH}}$ and $\mathrm{OH}$ anomalies in specific years at the precision required (1$2 \%$ ) to test CTM interannual variability.

\subsection{Methane lifetime sensitivity to chemistry-climate factors}

Having identified consistent variations in $\tau_{\mathrm{CH}_{4} \times \mathrm{OH}}$ across multiple CTMs, we examine their causes with explicit perturbation tests. In these tests, we perturb a single climate or emission variable, simulate 3 or more years, discard the first year as spinup, and analyze the difference from the unperturbed simulation in the remaining years. Perturbations are applied to 1997-1999 for Oslo CTM3 and the UCI CTM, and, because of meteorological data availability, to 2004 2006 for GEOS-Chem with GEOS-5. The sensitivity, $\alpha$, of $\tau_{\mathrm{CH}_{4} \times \mathrm{OH}}$ to a climate or emission variable, $F$, is always 
Table 2. Sensitivity of $\tau_{\mathrm{CH}_{4} \times \mathrm{OH}}$ to climate variables and emissions ${ }^{\mathrm{a}}$.

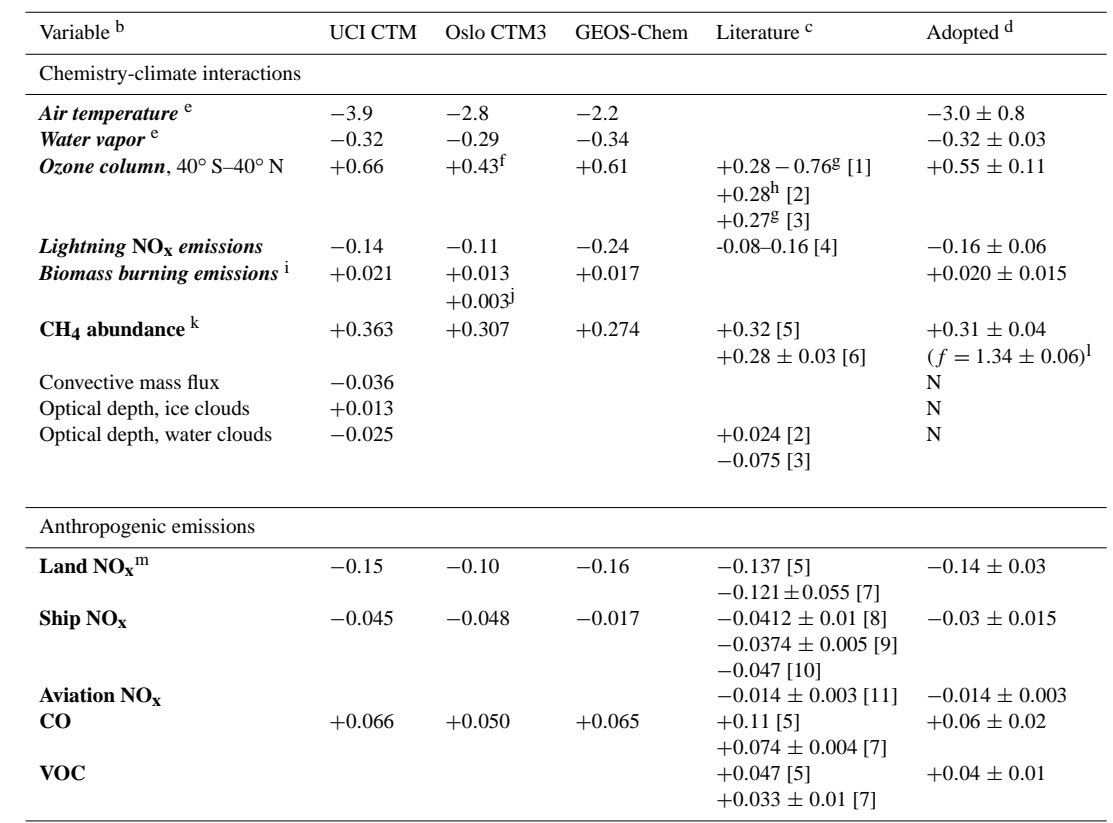

\footnotetext{
a Sensitivities are reported as $d \ln \left(\tau_{\mathrm{CH}_{4} \times \mathrm{OH}}\right) / d \ln (F)$ for each variable $F$, based on perturbation tests described in Sect. 3.2.

${ }^{b}$ Italic variables are major causes of interannual $\tau_{\mathrm{CH}_{4}} \times \mathrm{OH}$ changes (based on sensitivity and interannual changes in the variable) that are included the 1997-2009 reconstruction of CTM $\tau_{\mathrm{CH}_{4}} \times \mathrm{OH}$ in Sect. 3.3. Bold variables can drive decadal trends and are included in $1980-2100$ prediction of $\tau_{\mathrm{CH}} \times \mathrm{OH}$ in Sects. 4 and 5. c [1] Karlsdottir and Isaksen (2000), [2] Krol and van Weele (1997), [3] Voulgarakis et al. (2009), [4] Labrador et al. (2004), [5] Prather et al. (2001), [6] Fiore et al. (2009), [7] Fry et al. (2012), [8] Hoor et al. (2009), [9] Myhre et al. (2011), [10] Dalsoren et al. (2010), [11] Holmes et al. (2011)

$\mathrm{d}$ Adopted values are the mean of CTMs, except for VOC, and aviation $\mathrm{NO}_{\mathrm{X}}$, which come from literature. Uncertainties are 1- $\sigma$ values based on CTM spread and expert assessment of literature. Terms marked $\mathrm{N}$ have negligible impact on interannual $\tau_{\mathrm{CH}_{4}} \times \mathrm{OH}$ variability and are not used in the parametric model.

e Tropospheric perturbation only.

f In Oslo CTM3 stratospheric chemistry and stratosphere-troposphere exchange respond to the perturbation, whereas UCI CTM and GEOS-Chem responses are due solely to tropospheric photolysis rates. Oslo CTM3 results are rescaled to the same ozone column change as the other models.

g Response to global ozone column perturbation.

${ }^{\mathrm{h}}$ Response to extra-tropical ozone column perturbation (poleward of $30^{\circ}$ ).

i Sensitivities assume fire emissions are contained in the boundary layer, except where noted for Oslo CTM3. The UCI CTM value is the emission-weighted average sensitivity for 1997-2009 (Fig. 4). Values for other models are calculated from 3-yr perturbation tests and scaled to 1997-2009 means, assuming the same interannual variability as the UCI CTM. Adopted uncertainty accounts for uncertainty in emission altitude and year-to-year variability.

$\mathrm{j}$ Calculated with the RETRO altitude distribution, which injects $35 \%$ of equatorial (45\% of boreal) biomass burning emissions above $2 \mathrm{~km}$. Net sensitivity is lower because $\mathrm{NO}$ is longer lived at high altitudes and more effectively cancels the $\mathrm{CO}$ sink for $\mathrm{OH}$.

${ }^{\mathrm{k}}$ Sensitivity to $\mathrm{CH}_{4}$ abundance calculated from perturbations applied over 1997-2009 in UCI CTM and Oslo CTM3 and 2004-2009 in GEOS-Chem.

${ }^{1} f$ is the methane feedback factor, defined as the ratio of methane perturbation lifetime to total budget lifetime (Prather et al., 2001). We calculate $f$ using recent estimates of all methane sinks, Prather et al. (2012). Using IPCC TAR lifetimes increases $f$ by 0.03 .

$\mathrm{m}$ All anthropogenic $\mathrm{NO}_{\mathrm{x}}$ emission occurring on land, including combustion, agriculture, and waste.
}

defined as

$\alpha=d \ln \left(\tau_{\mathrm{CH}_{4} \times \mathrm{OH}}\right) / d \ln (F)$.

As such, $\alpha$ can be interpreted as the percent change in $\tau_{\mathrm{CH}_{4} \times \mathrm{OH}}$ resulting from a $1 \%$ increase in $F$.

Table 2 reports sensitivities for the evaluated climate and emission variables. These variables include most of those identified in the literature as important influences on tropospheric $\mathrm{OH}$ and $\tau_{\mathrm{CH}_{4} \times \mathrm{OH}}$ variability: temperature, water vapor, stratospheric ozone column, convective fluxes, cloud optical depth, biomass burning emissions, and anthropogenic emissions. Perturbation magnitudes are chosen to be similar to the interannual variability or decadal trend of each variable (exact magnitudes in Table S2). Perturbations are applied globally, except for stratospheric ozone, which is only perturbed over $40^{\circ} \mathrm{S}-40^{\circ} \mathrm{N}$, where tropospheric $\mathrm{OH}$ production from UV photolysis of tropospheric $\mathrm{O}_{3}$ occurs. The consequences of averaging region choice are discussed further in Sect. 3.3. Temperature and water vapor perturbations are restricted to the troposphere in Oslo CTM3, which includes full stratospheric chemistry, to avoid confounding changes in stratospheric ozone columns.

Only variables with large sensitivity, large interannual changes, or both can explain the year-to-year $\tau_{\mathrm{CH}_{4} \times \mathrm{OH}}$ variations identified in Fig. 1. Figure 3 shows the interannual changes of 5 key variables for 1997-2009. Water vapor, having about $3 \%$ variation and $\tau_{\mathrm{CH}_{4} \times \mathrm{OH}}$ sensitivity near -0.3 , could account for about $1 \%$ interannual variability in $\tau_{\mathrm{CH}_{4} \times \mathrm{OH}}$. Temperature, ozone column, lightning $\mathrm{NO}_{\mathrm{x}}$, and biomass burning also have sufficient sensitivity and variability to account for about $1 \%$ variation in $\tau_{\mathrm{CH}_{4} \times \mathrm{OH}}$. 

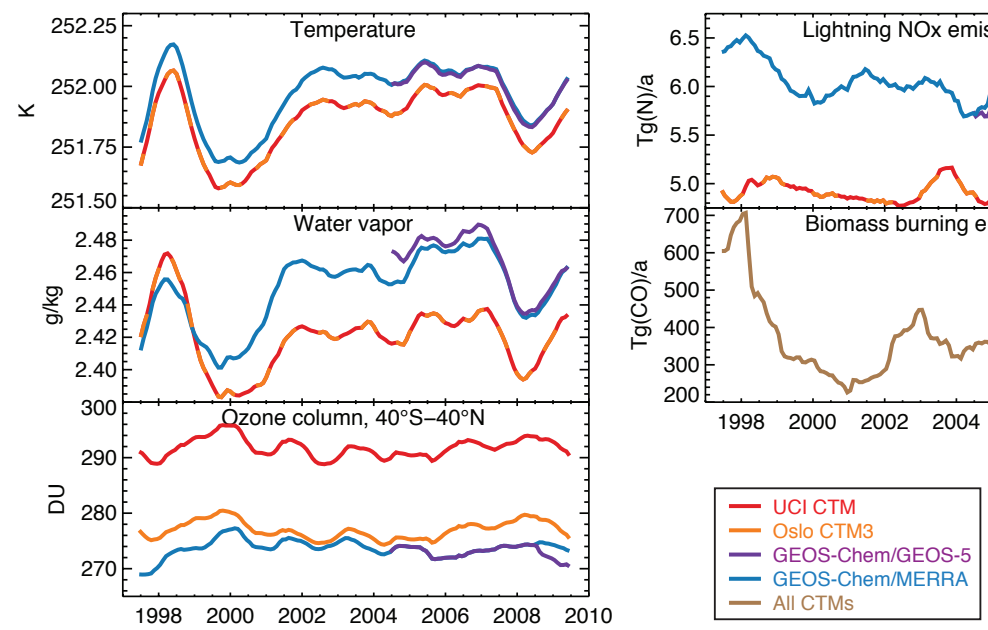

Fig. 3. Climate and emission variables controlling the interannual variation of $\tau_{\mathrm{CH}_{4} \times \mathrm{OH}}$ in CTMs. Emissions are global totals and other variables are global averages, except ozone columns, which are averaged over $40^{\circ} \mathrm{S}-40^{\circ} \mathrm{N}$. Colors show which inputs are used by each CTM.

These 5 climate and emission variables that we identify as important influences on $\tau_{\mathrm{CH}_{4} \times \mathrm{OH}}$ have been recognized previously, but their sensitivities have typically not been quantified in a comparable way (e.g. Spivakovsky et al., 2000; Dentener et al., 2003; Labrador et al., 2004; Stevenson et al., 2005; Fiore et al., 2006; Hess and Mahowald, 2009).

Convective fluxes and cloud optical depths for water and ice clouds, as diagnosed in ECMWF meteorology, vary annually by $2 \%$ and have small sensitivity $(-0.03$ to +0.01$)$, so these factors have very little impact on $\tau_{\mathrm{CH}_{4} \times \mathrm{OH}}(\ll 1 \%)$. Due to the small impact in the UCI CTM, these perturbation tests are not repeated in the other CTMs. Our results are consistent with the known decrease in mass-weighted global $\mathrm{OH}$ concentrations due to clouds (Voulgarakis et al., 2010) because mass-weighted averaging emphasizes below-cloud $\mathrm{OH}$ concentrations and we find compensating increases in methane loss above clouds. In addition, past analyses of convective fluxes have found both positive and negative influences on $\tau_{\mathrm{CH}_{4} \times \mathrm{OH}}$ depending on the convection scheme and perturbation used (Lawrence and Salzmann, 2008).

Methane abundance and anthropogenic $\mathrm{NO}_{\mathrm{x}}, \mathrm{CO}$, and VOC emissions vary smoothly between years, but changed by 1-2\% over the 2000-2010 (Dlugokencky et al., 2011; Granier et al., 2011). Therefore, these factors have little impact on $\tau_{\mathrm{CH}_{4} \times \mathrm{OH}}$ variability during the $13-\mathrm{yr}$ CTM simulation, but are important on multi-decadal time scales and longer.

Many of the sensitivity terms in Table 2 - specifically, water vapor, $\mathrm{CH}_{4}$ abundance, and anthropogenic land $\mathrm{NO}_{\mathrm{x}}$ and $\mathrm{CO}$ - are consistent among the CTMs and with past estimates (Prather et al., 2001; Fiore et al., 2006; Hoor et al., 2009; Myhre et al., 2011), suggesting a good understanding of how these variables impact tropospheric methane loss. Adopted values for each sensitivity (Table 2 , right column) reflect the

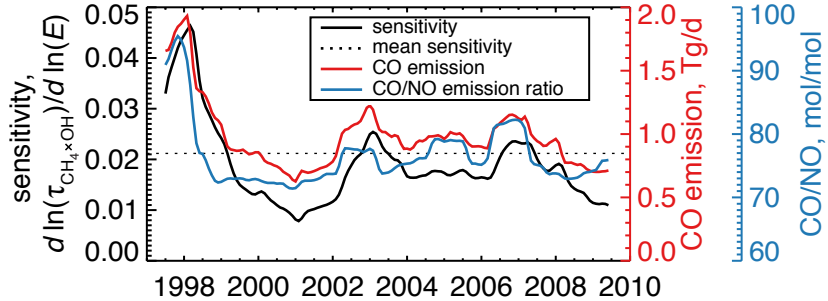

Fig. 4. Sensitivity of $\tau_{\mathrm{CH}_{4} \times \mathrm{OH}}$ to biomass burning emissions, $E$, in the UCI CTM. Biomass burning $\mathrm{CO}$ emissions and the $\mathrm{CO} / \mathrm{NO}$ emission ratio from the GFED3 inventory are also shown. Peak emissions and peak $\mathrm{CO} / \mathrm{NO}$ ratio occur during El Niño events, due to tropical peat fires.

degree of consistency among models. These adopted values are used in the parametric model described below.

For biomass burning, the CTMs show moderate agreement in the mean sensitivity when fires are assumed to emit into the boundary layer $(\alpha=0.013$ to 0.021$)$. The $\tau_{\mathrm{CH}_{4} \times \mathrm{OH}}$ response to biomass burning depends strongly on the emission altitude, however, since the net sensitivity results from offsetting $\mathrm{CO}$ and $\mathrm{NO}_{\mathrm{x}}$ effects and the $\mathrm{NO}_{\mathrm{x}}$ lifetime depends strongly on altitude. When using the RETRO vertical distribution for wildfire emissions in Oslo CTM3, in which 35$45 \%$ of emissions enter the free troposphere, the $\tau_{\mathrm{CH}_{4} \times \mathrm{OH}}$ sensitivity is 4 times smaller $(\alpha=0.003)$. This vertical distribution explains why Oslo CTM3 exhibits the least $\tau_{\mathrm{CH}_{4} \times \mathrm{OH}}$ variability in the 1997-2009 simulations (Fig. 1). Sensitivity to fires also changes dramatically between years, shown in Fig. 4 for the UCI CTM. The sensitivity is greatest during years with high biomass burning emissions, and high $\mathrm{CO} / \mathrm{NO}$ ratio in those emissions, both of which suppress tropospheric OH (Duncan et al., 2003; Dalsoren et al., 2006; Voulgarakis et al., 2010) and peak during El Niño years due to tropical 
peat fires. Future El Niño activity cannot be predicted robustly (Collins et al., 2010) and injection altitude distributions remain uncertain so, despite some CTM consensus on present-day biomass burning sensitivity, we adopt a broad uncertainty range for this sensitivity factor.

Other sensitivities, chiefly air temperature and ship $\mathrm{NO}_{\mathrm{x}}$, differ by $50 \%$ or more across the models. These differences are understandable, however, as consequences of modeling assumptions. For ship $\mathrm{NO}_{\mathrm{x}}$, Oslo CTM3 and UCI CTM are nearly 3 times more sensitive than GEOS-Chem. In the UCI CTM and Oslo CTM3, ship $\mathrm{NO}_{\mathrm{x}}$ is emitted as NO, diluted into the grid volume, and the subsequent production of $\mathrm{O}_{3}$ and $\mathrm{HNO}_{3}$ are calculated by the grid-resolved chemistry. Instantaneous dilution overestimates the $\mathrm{NO}_{\mathrm{x}}$ lifetime and $\mathrm{O}_{3}$ production from ships (Chen et al., 2005), however. To compensate, GEOS-Chem instantaneously converts all ship $\mathrm{NO}_{\mathrm{x}}$ emissions to $\mathrm{O}_{3}$ and $\mathrm{HNO}_{3}$, following observed production ratios. As a result, GEOS-Chem underestimates the largescale impact of shipping, since, in reality, $20-50 \%$ of $\mathrm{NO}_{\mathrm{x}}$ remains after $5 \mathrm{~h}$ following emission (Vinken et al., 2011). Although previous estimates of ship $\mathrm{NO}_{\mathrm{x}}$ are close to the high values in this work (Hoor et al., 2009; Myhre et al., 2011), the actual atmospheric sensitivity to ship $\mathrm{NO}_{\mathrm{x}}$, likely lies somewhere between the GEOS-Chem and UCI CTM results.

Ship $\mathrm{NO}_{\mathrm{x}}$ emissions also explain the divergence of GEOSChem and the UCI CTM in their temperature sensitivities. Over land, both models predict similar reduction in $\tau_{\mathrm{CH}_{4} \times \mathrm{OH}}$ in response to warming. Over the oceans, however, GEOSChem predicts longer $\tau_{\mathrm{CH}_{4} \times \mathrm{OH}}$ at higher temperatures while the UCI CTM predicts the opposite. In the presence of ship $\mathrm{NO}_{\mathrm{x}}$ in the UCI CTM, higher temperatures increase both the production and loss of $\mathrm{O}_{3}$, with net excess production; $\mathrm{OH}$ rises in turn. In GEOS-Chem, by contrast, higher temperatures increase $\mathrm{O}_{3}$ destruction over the ocean with less opportunity for enhanced production; $\mathrm{OH}$ thus decreases over oceans.

The sensitivity of $\tau_{\mathrm{CH}_{4} \times \mathrm{OH}}$ to methane abundance is closely related to the methane feedback factor, $f$, which is the ratio of methane perturbation lifetime to total budget lifetime (Prather et al., 2001). We calculate these terms from a 5\% perturbation to methane abundance for 1997-2009 in the CTMs. Our multi-model mean sensitivity, $0.31 \pm 0.04$, is similar to past estimates (Prather et al., 2001; Fiore et al., 2009), but we derive a smaller feedback factor $f=$ $1.34 \pm 0.06$ than has been recommended by IPCC ( $f=$ 1.4, Prather et al., 2001) because we use updated estimates of methane lifetime (Prather et al., 2012). Reducing the feedback factor, which was already suggested by Fiore et al. (2009), lowers the methane radiative forcing and global warming potential, as discussed in Sect. 6.

\subsection{A parametric model for $\tau_{\mathrm{CH}_{4} \times \mathrm{OH}}$}

The sensitivity parameters in Table 2 , together with the time series of corresponding climate and emission variables in Fig. 3, enable us to build a parametric model for methane lifetime representing each CTM. We combine terms linearly, so that $\tau_{\mathrm{CH}_{4} \times \mathrm{OH}}$ is approximated by

$\ln \left(\tau_{\mathrm{CH}_{4} \times \mathrm{OH}}(t)\right)=\ln \left(\left\langle\tau_{\mathrm{CH}_{4} \times \mathrm{OH}}\right\rangle\right)+\Sigma_{i} \alpha_{i} \Delta \ln \left(F_{i}(t)\right)$,

where $F_{i}(t)$ is the time series of forcing variable $i, \alpha_{i}$ is the sensitivity of $\tau_{\mathrm{CH}_{4} \times \mathrm{OH}}$ to that forcing variable (Eq. 2), and $\left\langle\tau_{\mathrm{CH}_{4} \times \mathrm{OH}}\right\rangle$ is the mean lifetime in the CTM. Figure 1 shows the parametric model reconstruction of each CTM, alongside the actual calculated $\tau_{\mathrm{CH}_{4} \times \mathrm{OH}}$. We find that 5 variables - temperature, water vapor, column ozone, biomass burning emissions, and lightning $\mathrm{NO}_{\mathrm{x}}$ emissions - explain $90 \%$ of the interannual variation in $\tau_{\mathrm{CH}_{4} \times \mathrm{OH}}$ in all $3 \mathrm{CTMs}$ over the simulated period 1997-2009. Even though the GEOS-Chem sensitivity parameters were derived from $2^{\circ} \times 2.5^{\circ}$ simulations driven by GEOS-5, the 5-parameter model performs equally well compared to the $4^{\circ} \times 5^{\circ}$ GEOS-Chem simulation driven by MERRA. The sensitivity parameters are thus robust across changes in model resolution and meteorology.

We find that $85 \%$ of methane oxidation by tropospheric $\mathrm{OH}$ occurs between $40^{\circ} \mathrm{S}$ and $40^{\circ} \mathrm{N}$ and that this region also controls the interannual variability of $\tau_{\mathrm{CH}_{4} \times \mathrm{OH}}$ in the CTMs. The same latitudes also dominate the variability of globalmean temperature, water vapor, lightning NOx and biomass burning, so the parametric model performs nearly as well if these input variables are averaged over $40^{\circ} \mathrm{S}$ to $40^{\circ} \mathrm{N}$ instead of globally. Stratospheric ozone exerts the greatest influence on $\tau_{\mathrm{CH}_{4} \times \mathrm{OH}}$ over the same tropical and subtropical, where UV photolysis of tropospheric ozone is an important primary source of tropospheric $\mathrm{OH}$ and where the quasibiennial oscillation is the dominant source of stratospheric ozone variability. However, global-mean ozone columns are strongly influenced by variability in the springtime polar regions, so using global-average ozone columns significantly degrades the parametric model correlation with the CTMs $\left(R^{2} \approx 0.75\right)$.

The atmospheric chemistry of tropospheric $\mathrm{OH}$ and methane involves nonlinear chemistry that could, in principle, undermine the additivity of terms in Eq. (3). We test the linearity of the system with a final perturbation test in the UCI CTM in which all 5 factors are perturbed simultaneously. The resulting change in $\tau_{\mathrm{CH}_{4} \times \mathrm{OH}}$ differs by about 1 part in 10 from the linear addition of factors.

The CTM simulations in this work make several assumptions to simplify the perturbation analysis and enable comparisons between CTMs, but these could alter $\tau_{\mathrm{CH}_{4} \times \mathrm{OH}}$. In particular, the simulations neglect variability in biogenic VOC emissions (Guenther et al., 2006), trends in anthropogenic emissions and their location, and trends in atmospheric methane. We compare our GEOS-Chem/MERRA simulation to an available GEOS-Chem simulation (M. Mu, 
Table 3. Datasets used to calculate historical and future $\tau_{\mathrm{CH}_{4} \times \mathrm{OH}}$.

\begin{tabular}{|c|c|c|c|c|}
\hline \multirow[b]{2}{*}{ Variable } & \multicolumn{4}{|c|}{ Dataset } \\
\hline & $\begin{array}{l}\text { Historical } \\
(1980-2005)\end{array}$ & Source ${ }^{\mathrm{a}}$ & $\begin{array}{l}\text { Future } \\
(2010-2100)\end{array}$ & Source $^{\mathrm{a}}$ \\
\hline Air temperature & MERRA & {$[1]$} & $\mathrm{CMIP5}^{\mathrm{b}}$ & {$[5]$} \\
\hline Water vapor & MERRA & {$[1]$} & CMIP5 $^{b}$ & [5] \\
\hline Ozone column & TOMS/SBUV & [2] & SPARC & [6] \\
\hline Lightning $\mathrm{NO}_{\mathrm{x}}$ & $0 \pm 10 \%$ & Assumed & $+10 \pm 20 \%$ & Assumed \\
\hline Biomass burning & CMIP5 & [3] & $\mathrm{RCP} 8.5$ & {$[7]$} \\
\hline $\begin{array}{l}\text { Anthropogenic emissions } \\
\left(\mathrm{NO}_{\mathrm{x}}, \mathrm{CO}, \mathrm{VOC}\right)\end{array}$ & CMIP5 & {$[3]$} & $\mathrm{RCP} 8.5$ & [7] \\
\hline $\mathrm{CH}_{4}$ abundance & CMIP5 & {$[4]$} & this work ${ }^{\mathrm{c}}$ & \\
\hline
\end{tabular}

a [1] Bosilovich et al. (2011), [2] Stolarski and Frith (2006), [3] Schultz et al. (2008); Eyring et al. (2010b); Lamarque et al. (2010); Lee et al. (2010), [4] CMIP5 historical GHG recommendations, Meinshausen et al. (2011b) [5] Ensemble of 35 CMIP5 models (Climate Explorer, http://climexp.knmi.nl/, accessed 18 December 2012) [6] CCM-Val2 multimodel mean for SRES A1B greenhouses gases and A2 ozone depleting substances (Austin and Scinocca, 2010; Eyring et al., 2010a), uncertainties assumed to be $\pm 3 \%$ in 2100. [7] Riahi et al. (2007); van Vuuren et al. (2011).

${ }^{\mathrm{b}}$ Future air temperature, water vapor and their uncertainties are calculated from global-mean surface temperatures in the CMIP5 model ensemble. See Supplement for details.

c Calculated from the parametric model, as explained in Sect. 5.

personal communication, 2012) that includes these trends and variability in emissions, uses identical meteorology and resolution, and has minor other changes (version 9-01$01)$. The two model configurations simulate very similar $\tau_{\mathrm{CH}_{4} \times \mathrm{OH}}\left(R^{2}=0.98\right)$ over $1999-2009$, meaning that year-toyear changes in biogenic and anthropogenic emissions contribute little additional $\tau_{\mathrm{CH}_{4} \times \mathrm{OH}}$ variability and do not alter the key parametric factors.

\section{Historical (1980-2005) changes in $\mathrm{CH}_{4}$ lifetime}

Having established the ability of Eq. (3) to reconstruct $\tau_{\mathrm{CH}_{4} \times \mathrm{OH}}$ over 1997-2009 in CTMs, we now use it to extrapolate methane lifetime over several decades for which the CTMs have not been run. We begin with the historical period 1980-2005, during which time the key atmospheric forcing variables have been relatively well observed by satellites and ground stations.

In addition to the 5 climate and emission variables identified in Sect. 3.2 and 3.3 as important influences on interannual variability, we include $\mathrm{CH}_{4}$ abundance and anthropogenic $\mathrm{NO}_{\mathrm{x}}, \mathrm{CO}$ and VOC emissions for the historical reconstruction. $\mathrm{NO}_{\mathrm{x}}$ emissions are divided into land, ship and aviation sectors because their sensitivities differ significantly. In total, the expanded parametric model includes 11 variables. For the 11 sensitivity parameters, $\alpha_{i}$ in Eq. (3), we adopt values from the average and spread of sensitivities in the 3 CTMs (Table 2, last column).

Table 3 summarizes the data sources for historical climate and emission variables in the expanded parametric model. NASA MERRA reanalysis provides temperature and water vapor data (Bosilovich et al., 2011) and satellite observa- tions provide ozone column data (Stolarski and Frith, 2006). As with the 5-parameter model, ozone columns are averaged over the $40^{\circ} \mathrm{S}$ to $40^{\circ} \mathrm{N}$ and other data are global averages. Historical $\mathrm{CH}_{4}$ abundance and anthopogenic and biomass burning emissions follow CMIP5 recommendations (Lamarque et al., 2010; Meinshausen et al., 2011b). Global annual lightning flash rates have varied by up to $20 \%$ since 1998 , but multi-decadal trends are not apparent (Murray et al., 2012), so we assume no change since 1980 , with $10 \%$ Gaussian uncertainty in the trend.

Figure 5 shows the reconstructed historical changes in $\tau_{\mathrm{CH}_{4} \times \mathrm{OH}}$ and the contribution to those changes from each climate and emission variable. We assess uncertainty in $\tau_{\mathrm{CH}_{4} \times \mathrm{OH}}$ by generating $10^{5}$ monte carlo realizations of Eq. (3), allowing all parameters, $\alpha_{i}$, and lightning to vary independently within their uncertainties. This does not account for possible errors in emissions, ozone observations, or meteorological assimilation that are difficult to quantify. (See Fig. S6 for uncertainties in $\tau_{\mathrm{CH}_{4} \times \mathrm{OH}}$ due to each component.)

Our reconstructed $\tau_{\mathrm{CH}_{4} \times \mathrm{OH}}$ has annual variability of $1-$ $2 \%$ over the 1980-2005 period. Reductions in $\tau_{\mathrm{CH}_{4} \times \mathrm{OH}}$ occur during El Niño years (1982-1983, 1987-1988, and 1997-1998) driven mainly by water vapor and reinforced by a smaller effect from temperature. $\tau_{\mathrm{CH}_{4} \times \mathrm{OH}}$ is also depressed through much of the 1990s when stratospheric ozone was low, due to the solar cycle and Mt. Pinatubo, enhancing UV penetration and photolysis in the troposphere. The largest spikes in $\tau_{\mathrm{CH}_{4} \times \mathrm{OH}}$ occur when the solar cycle maximum and La Niña are synchronous, as in 1989 and 19992000. Overall, the parametric model simulates a decrease in $\tau_{\mathrm{CH}_{4} \times \mathrm{OH}}$ since 1980 , which has also been found in numerous CTM and GCM studies (Duncan et al., 2000; Karlsdottir 

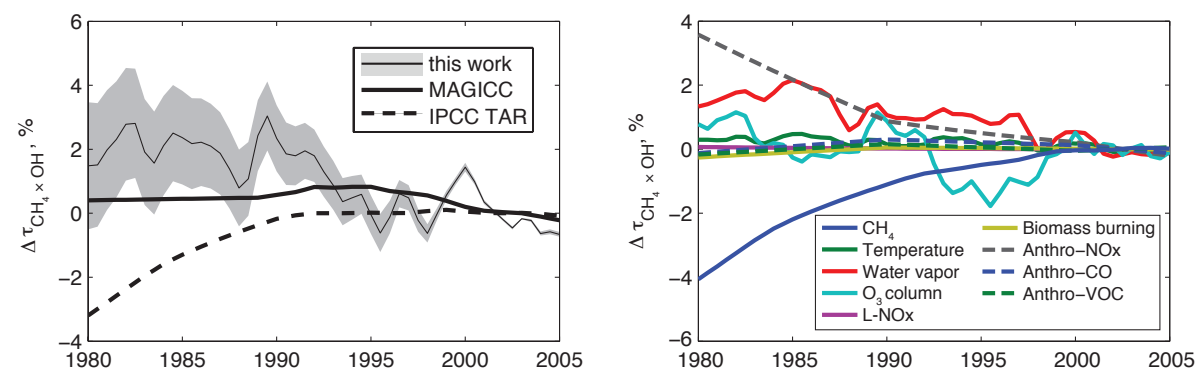

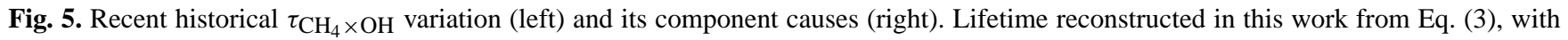
components shown at right. Shaded region shows $\pm \sigma$ uncertainty propagated from adopted parameter ranges in Table 2 , but not including possible errors in reanalysis meteorology, ozone column observations, or emission inputs. All data are anomalies with respect to their 20002005 means. The anthropogenic (anthro) $\mathrm{NO}_{\mathrm{x}}$ component combines the separate effects of land, ship, and aircraft emissions. See Fig. S6 for uncertainties in each component.

and Isaksen, 2000; Dentener et al., 2003; Stevenson et al., 2005; Hess and Mahowald, 2009; John et al., 2012; Naik et al., 2012). This is an improvement over previous parametric approaches, which are shown in Fig. 5, that produce zero or positive trends over the same period (Prather et al., 2001; Meinshausen et al., 2011a).

Figure 6 identifies the contribution of each variable to the total change in $\tau_{\mathrm{CH}_{4} \times \mathrm{OH}}$. Rising atmospheric methane has the largest influence on $\tau_{\mathrm{CH}_{4} \times \mathrm{OH}}$, but the positive methane feedback effect $(3.5 \%)$ is more than compensated by negative climate and emission terms. Temperature and water vapor, which have increased due to GHGs, decrease $\tau_{\mathrm{CH}_{4} \times \mathrm{OH}}$ by $2 \%$, collectively, although the water vapor effect is about 3 times larger. Halogen-driven decreases in stratospheric ozone also shortened the lifetime about $1 \%$. Increases in ship and land anthropogenic $\mathrm{NO}_{\mathrm{x}}$ emissions both decrease $\tau_{\mathrm{CH}_{4} \times \mathrm{OH}}$ by $1.5 \%$, despite the ship source having much smaller total magnitude. Lightning $\mathrm{NO}_{\mathrm{x}}$ could also have an important impact on $\tau_{\mathrm{CH}_{4} \times \mathrm{OH}}$, but the lightning trends are not known.

The total $\tau_{\mathrm{CH}_{4} \times \mathrm{OH}}$ change from $1980-1985$ to $2000-2005$ is $-2.2 \pm 1.8 \%$ in our model, or $-0.12 \% \mathrm{yr}^{-1}$ from a linear fit. Dentener et al. (2003), simulated a larger decrease, $-0.2 \% \mathrm{yr}^{-1}$, in the $1980 \mathrm{~s}$ that they attributed mainly to water vapor. Meteorological inputs may contribute to the difference, since water vapor trends are known to vary amongst reanalysis products (Trenberth et al., 2011). In addition, the shift of anthropogenic emissions to SE Asia, which alters the sensitivity of $\tau_{\mathrm{CH}_{4} \times \mathrm{OH}}$ to emissions is not treated in the parametric model (e.g. Fuglestvedt et al., 1999; Karlsdottir and Isaksen, 2000). Methyl chloroform analyses generally suggest large decreases in $\tau_{\mathrm{CH}_{4} \times \mathrm{OH}}$ during the 1980 s followed by increases during the 1990s, which conflicts with the CTM results (Bousquet et al., 2005; Prinn et al., 2005). Assuming uncertainty of about $20 \%$ in methyl chloroform emissions, however, reconciles the observations with the small trends found in CTMs and in our parametric model (Krol and Lelieveld, 2003; Prinn et al., 2005).

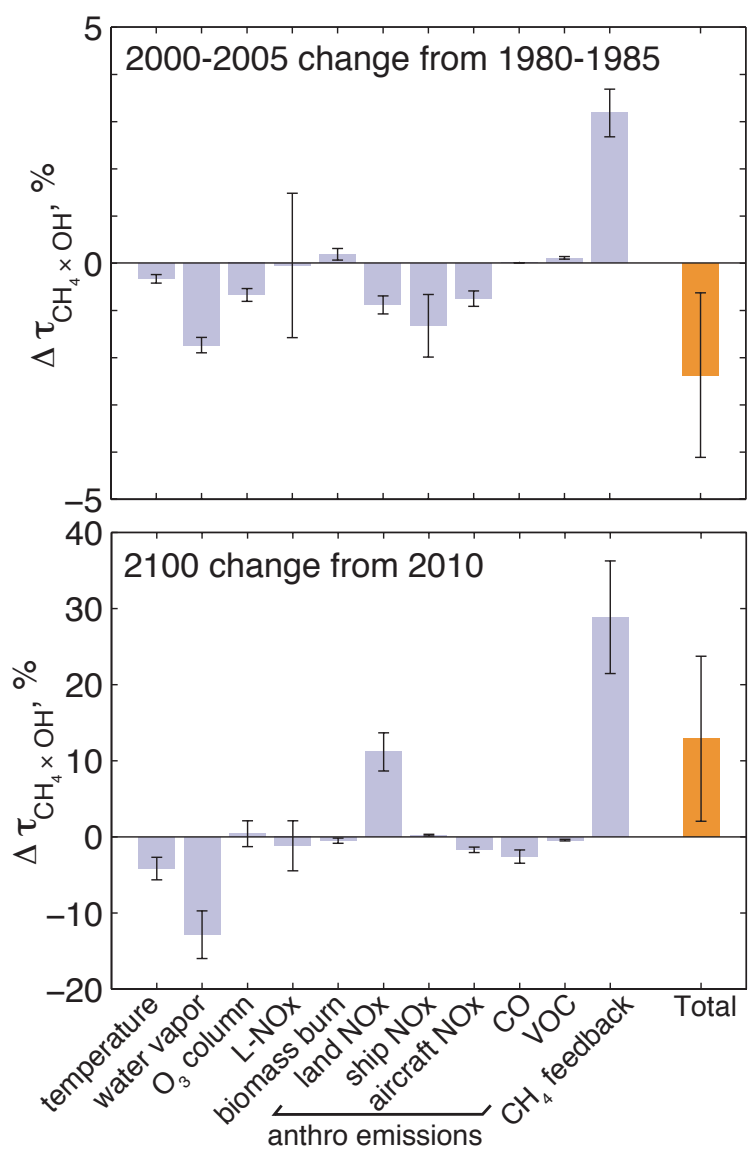

Fig. 6. Contribution of emissions and chemistry-climate interactions to changes in $\tau_{\mathrm{CH}_{4}} \times \mathrm{OH}$ from 1980 to 2005 (top) and from 2010 to 2100 (bottom). Components and their uncertainties are derived from adopted parameters in Table 2 and forcing variables in Table 3. Uncertainties (vertical bars) are standard deviations from $10^{5}$ monte carlo integrations. Changes are averaged over the 5 years at the beginning and end of the historical reconstruction due to interannual variability. Note the different vertical scales. 

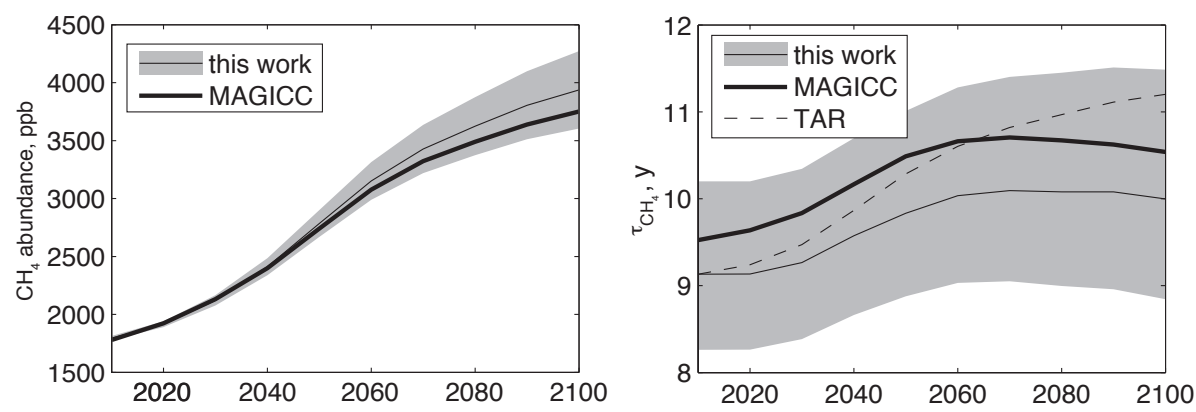

Fig. 7. Projected future methane abundance (left) and total lifetime (right) for RCP 8.5. Projected uncertainty (shaded) is the standard deviation from $10^{5}$ monte carlo integrations, accounting for uncertainty in the present-day budget, emissions, and climate-chemistry effects on $\tau_{\mathrm{CH}_{4} \times \mathrm{OH}}$. Our projections are compared to MAGICC model (Meinshausen et al., 2011a) and the IPCC TAR formula (Prather et al., 2001).

\section{Future (2010-2100) $\mathrm{CH}_{4}$ and $\mathrm{CH}_{4}$ lifetime}

We now apply the parametric model to predict methane and methane lifetime, with their uncertainties, for a future socioeconomic scenario. We make predictions for RCP 8.5 (Riahi et al., 2007), a scenario with rapid climate warming, but these methods apply to other scenarios as well. The prediction begins with the best estimate of present-day (2010) methane budget, including natural $\left(202 \pm 35 \mathrm{Tg} \mathrm{yr}^{-1}\right)$ and anthropogenic $\left(352 \pm 45 \mathrm{Tg} \mathrm{yr}^{-1}\right)$ emissions and lifetimes for loss by tropospheric $\mathrm{OH}(11.2 \pm 1.3 \mathrm{yr})$, tropospheric $\mathrm{Cl}(200 \pm 100 \mathrm{yr})$, stratospheric reactions $(120 \pm 24 \mathrm{yr})$, and soil uptake $(150 \pm 50 \mathrm{yr})$ (Prather et al., 2012). The scenario specifies future anthropogenic methane emissions and we assume natural emissions could change $\pm 20 \%(1 \sigma)$ by 2100 due to climate feedbacks, which is about twice the change in wetland emissions since the preindustrial era (Houweling et al., 2000). We use the parametric model to predict future $\tau_{\mathrm{CH}_{4} \times \mathrm{OH}}$ and assume other loss rates are constant. For future predictions we use the same expanded set of 11 parameters as were used in the historical $\tau_{\mathrm{CH}_{4} \times \mathrm{OH}}$ reconstruction (Table 2, last column). Table 3 lists data sources for the future climate and emission variables. We then generate $10^{5}$ monte carlo realizations of future methane abundance in RCP 8.5, sampling over the uncertainties in all parametric factors and forcing variables in Eq. (3), as well as uncertainties in the present-day methane budget.

Table 4 summarizes the predicted changes in climate and emissions in RCP 8.5. In this scenario most anthropogenic emissions of ozone precursors decrease by 2100 (7-75\%), although aircraft $\mathrm{NO}_{\mathrm{x}}$ emissions rise $123 \%$. Biomass burning emissions, also specified by the scenario, decrease $35 \%$, which we assume applies uniformly to all gases and aerosols from fires. The parametric model requires future globalmean air temperature and water vapor inputs consistent with the scenario. We calculate these from global-mean surface temperature in CMIP5 models that have simulated RCP 8.5 (Climate Explorer, http://climexp.knmi.nl/, accessed 18 December 2012) using the strong regression relationship be-
Table 4. Changes (2100-2010) in climate, emissions, and $\tau_{\mathrm{CH}_{4} \times \mathrm{OH}}$ for RCP $8.5^{*}$.

\begin{tabular}{lll}
\hline Variable & Variable change & $\begin{array}{l}\tau_{\mathrm{CH}_{4} \times \mathrm{OH}} \\
\text { change, } \%\end{array}$ \\
\hline Air temperature & $+3.6 \pm 0.9 \mathrm{~K}$ & $-4.2 \pm 1.5$ \\
Water vapor & $+43.2 \pm 9.5 \%$ & $-12.9 \pm 3.1$ \\
Ozone column, $40^{\circ} \mathrm{S}-40^{\circ} \mathrm{N}$ & $+0.7 \pm 3.0 \%$ & $+0.4 \pm 1.7$ \\
Lightning $\mathrm{NO}_{\mathrm{x}}$ emissions & $+10 \pm 20 \%$ & $-1.2 \pm 3.3$ \\
Biomass burning emissions $_{\mathrm{CH}_{4} \text { abundance }}-34.8 \%$ & $+0.5 \pm 0.3$ \\
\hline Anthropogenic emissions & $+78.2 \pm 8.4 \%$ & $+28.9 \pm 7.4$ \\
\hline Land NO & & \\
Ship NO & $-75.3 \%$ & $+11.2 \pm 2.5$ \\
Aircraft NO & & $+0.2 \pm 0.1$ \\
$\mathrm{CO}$ & $-7.2 \%$ & $-1.7 \pm 0.4$ \\
VOC & $+123 \%$ & $-2.6 \pm 0.9$ \\
\hline Total (this work) & $-44.0 \%$ & $-0.4 \pm 0.1$ \\
IPCC TAR Total, Prather et al. (2001) & $+12.9 \pm 10.8$ \\
MAGICC Total, Meinshausen et al. $(2011 \mathrm{a})$ & +12.6 \\
\hline
\end{tabular}

* Variable changes from data sources in Table 3, except $\mathrm{CH}_{4}$ abundance, which is calculated parametric model, as described in Sect. 5. $\tau_{\mathrm{CH}_{4} \times \mathrm{OH}}$ component changes derive from the variable changes and the sensitivities in Table 2, including uncertainties in both. Uncertainties are standard deviations from $10^{5}$ monte carlo realizations.

tween annual-mean surface temperature, air temperature and water vapor that we derive from historical reanalysis data since 1979 (See Supplement for details). We use global-mean surface temperatures to drive the parametric model because these data are more easily available and because this simplifies future applications of the parametric model to other climate scenarios. The range of future surface temperatures in the CMIP5 ensemble is propagated to uncertainty in future air temperature and water vapor using regression fitting errors from the historical reanalysis. In 2100, we calculate air temperature and water vapor to be $3.6 \pm 0.9 \mathrm{~K}$ and $43.2 \pm 9.5 \%$ larger than 2010 , respectively. For tropical stratospheric ozone, multiple models predict recovery 
to 1980 levels around 2045 due to the decrease of longlived halogenated gases (Newman et al., 2007; Austin and Scinocca, 2010; Eyring et al., 2010a), followed by GHGdriven ozone decreases through 2100 (Eyring et al., 2010a). We adopt this projection, adding uncertainty that grows to $3 \%$ of the total column in 2100. Lightning $\mathrm{NO}_{\mathrm{x}}$ emissions have been estimated in past work to grow $5-50 \%$ by the late 21 st century (Wu et al., 2008), but these predictions are highly speculative due to poor mechanistic understanding of present-day global flash rates. GHG-driven climate warming tends to reduce convection globally (Held and Soden, 2006), but could intensify convection in some regions (Del Genio et al., 2007), so the total effect on lightning is unclear. In this work we assume $10 \%$ increase by 2100 , but allow broad Gaussian uncertainty of $20 \%$.

Figure 7 shows future methane and its uncertainty. Projected abundances reach $3990 \pm 330 \mathrm{ppb}$ in 2100 , which is about $400 \mathrm{ppb}$ lower than our previous work (Prather et al., 2012), which did not account for emissions and climate controls on $\tau_{\mathrm{CH}_{4} \times \mathrm{OH}}$. MAGICC predicts lower concentrations, $3750 \mathrm{ppb}$, due mainly to the strong negative sensitivity of $\tau_{\mathrm{CH}_{4} \times \mathrm{OH}}$ to temperature in that model, but the MAGICC values lie within our estimated uncertainties throughout the 21st century. Statistical uncertainties in methane predictions are $8 \%$ in 2100 , based on the assessed processes in the parametric model. Neglected processes - including shifting emission locations, biogenic VOC emissions, stratosphere-troposphere exchange, and cloud, dust and aerosol interactions with photolysis and chemistry might cause additional systematic prediction errors, but we have found that including these processes in one model (GEOS-Chem/MERRA) has little impact on present-day

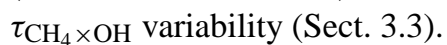

The parametric model predicts $\tau_{\mathrm{CH}_{4} \times \mathrm{OH}}$ will increase $+12.9 \pm 10.8 \%$ by 2100 (Fig. 7). MAGICC gives similar results $(+12.6 \%)$, but the IPCC TAR formula yields a larger result $(+29.7 \%)$, consistent with their respective historical performances in Sect. 4. The ACCMIP model ensemble predicts $+8.5 \pm 10.4 \%$ for RCP 8.5 (Voulgarakis et al., 2012). Lightning $\mathrm{NO}_{\mathrm{x}}$ emissions likely explain the $\tau_{\mathrm{CH}_{4} \times \mathrm{OH}}$ difference, since ACCMIP models calculate $24 \pm 29 \%$ increase in 2100 (Voulgarakis et al., 2012), compared to our assumed increase of $10 \pm 20 \%$. Although we do not think future lightning estimates from GCMs are robust (see above), assuming an equally large lightning change in the parametric model would lower $\tau_{\mathrm{CH}_{4} \times \mathrm{OH}}$ in 2100 by about $5 \%$, after including the methane feedback. The similar central estimates and ranges of $\tau_{\mathrm{CH}_{4} \times \mathrm{OH}}$ change in this work and ACCMIP, after accounting for different lightning assumptions, demonstrates that our simple parametric model represents the major chemistry-climate interactions and uncertainties affecting methane in current GCMs. This supports using the parametric model for climate scenarios where a large ensemble of GCMs with chemistry is not available and too costly to generate.
Figure 6 and Table 4 decompose the net $\tau_{\mathrm{CH}_{4} \times \mathrm{OH}}$ changes in 2100 into components due to each climate and emission variable. For emission terms, all uncertainty comes from the sensitivity parameter since the scenario emissions are taken as given, while uncertainty in other terms is a combination of possible errors in the forcing variable and sensitivity. Methane feedback has the largest influence, with an individual contribution of $+28.9 \pm 7.4 \%$. $\mathrm{NO}_{\mathrm{x}}$ emission reductions over land also force $\tau_{\mathrm{CH}_{4} \times \mathrm{OH}}$ upwards $(+11.2 \pm 2.5 \%)$, which is opposite to $\mathrm{NO}_{\mathrm{x}}$ influence in recent decades. Other climate and emission components are zero or negative, with water vapor having the largest effect $(-12.9 \pm 3.1 \%)$. Stratospheric ozone and lightning $\mathrm{NO}_{\mathrm{x}}$ contribute little to $\tau_{\mathrm{CH}_{4} \times \mathrm{OH}}$ changes, but they make a significant contribution to the uncertainty. MAGICC predicts similar $\tau_{\mathrm{CH}_{4} \times \mathrm{OH}}$ changes to the parametric model because its temperature response is similar to the combined effects of temperature and water vapor in our work, and sensitivities to the other dominant terms land $\mathrm{NO}_{\mathrm{x}}$ and methane feedback - have changed little since the IPCC TAR, on which MAGICC is based. The parametric model and MAGICC will differ in socioeconomic and climate scenarios where other emissions, ozone, or lightning drive $\tau_{\mathrm{CH}_{4} \times \mathrm{OH}}$ changes.

\section{Methane global warming potential}

Global Warming Potentials (GWP) are useful for comparing the radiative forcing (RF) caused by emissions of various GHGs having different absorbances and atmospheric lifetimes. The methane GWP customarily accounts for the direct RF from the emitted gas, as well as indirect RF caused by methane-induced increases in ozone, stratospheric water vapor, and feedback on the methane lifetime (Forster et al., 2007). Here we evaluate the methane GWP implied by the perturbation experiments. Radiative forcing of methane and ozone are calculated for the control simulation and a simulation with $5 \%$ more methane, using the University of Oslo radiative transfer model (Myhre et al., 2011). A small perturbation is used to satisfy the linearity assumption in the methane feedback factor derivation. In addition, we test the effect of methane-induced water vapor on stratospheric ozone, with an additional Oslo CTM3 simulation in which stratospheric water vapor was increased to maintain equilibrium with the $\mathrm{CH}_{4}$ perturbation. To our knowledge, this indirect, $\mathrm{H}_{2} \mathrm{O}$-mediated effect on ozone has not been included in prior assessments of methane GWP.

Table 5 summarizes ozone changes and RF results for all simulations, normalized to $1 \mathrm{ppb} \mathrm{CH}_{4}$ perturbations. Tropospheric ozone changes in GEOS-Chem and the UCI CTM (2.9 and 4.0 DU ppm $\left(\mathrm{CH}_{4}\right)^{-1}$, respectively) are within the range of previous multi-model studies (Holmes et al., 2011; Boucher, 2012; Fry et al., 2012). Oslo CTM3, however, exhibits larger tropospheric changes (5.1 DU ppm $\left(\mathrm{CH}_{4}\right)^{-1}$ ), likely due to the effects of stratospheric chemistry on the 
Table 5. Present-day, steady-state methane impact on ozone and radiative forcing ${ }^{\mathrm{a}}$.

\begin{tabular}{|c|c|c|c|c|c|}
\hline & UCI CTM & Oslo CTM3 & GEOS-Chem & Literature & Adopted \\
\hline \multicolumn{6}{|c|}{ Ozone chemistry, $\mathrm{DU}\left(\mathrm{O}_{3}\right) \mathrm{ppm}\left(\mathrm{CH}_{4}\right)^{-1}$} \\
\hline $\mathrm{d}\left[\mathrm{O}_{3}\right] / \mathrm{d}\left[\mathrm{CH}_{4}\right]$ & $4.03(\mathrm{~T})$ & $\begin{array}{l}5.08(\mathrm{~T}) \\
10.39(\mathrm{~S})\end{array}$ & $2.90(\mathrm{~T})$ & $\begin{array}{l}3.5 \pm 1.0(\mathrm{~T})^{\mathrm{b}} \\
3.0 \pm 0.8(\mathrm{~T})^{\mathrm{c}}\end{array}$ & \\
\hline $\mathrm{d}\left[\mathrm{O}_{3}\right] / \mathrm{d}\left[\mathrm{H}_{2} \mathrm{O}\right]\left(\right.$ from $\left.\mathrm{CH}_{4}\right)$ & & $\begin{array}{l}-0.41(\mathrm{~T}) \\
-4.28(\mathrm{~S})\end{array}$ & & & \\
\hline \multicolumn{6}{|c|}{ Radiative forcing, $\mathrm{mW} \mathrm{m}^{-2} \mathrm{ppm}\left(\mathrm{CH}_{4}\right)^{-1}$} \\
\hline $\mathrm{CH}_{4}$ & 367 & 367 & 367 & $370 \pm 27^{\mathrm{d}}$ & 370 \\
\hline $\mathrm{O}_{3}$ from $\mathrm{CH}_{4}$ & $141(\mathrm{~T})$ & $\begin{array}{l}202(\mathrm{~T}) \\
82(\mathrm{~S})\end{array}$ & $123(\mathrm{~T})$ & $126 \pm 45(\mathrm{~T})^{\mathrm{b}}$ & $\begin{array}{l}150(\mathrm{~T}) \\
82(\mathrm{~S})\end{array}$ \\
\hline $\mathrm{O}_{3}$ from $\mathrm{CH}_{4}$ via $\mathrm{H}_{2} \mathrm{O}$ & & $\begin{array}{l}-17(\mathrm{~T}) \\
-20(\mathrm{~S})\end{array}$ & & & $\begin{array}{l}-17(\mathrm{~T}) \\
-20(\mathrm{~S})\end{array}$ \\
\hline $\begin{array}{l}\mathrm{H}_{2} \mathrm{O} \text { from } \mathrm{CH}_{4} \\
\text { Total radiative forcing }\end{array}$ & & & & $55^{\mathrm{e}}$ & $\begin{array}{l}55 \\
620\end{array}$ \\
\hline 100-yr GWP & & & & $\begin{array}{l}25^{\mathrm{d}} \\
24.2 \pm 4.2^{\mathrm{c}} \\
25.3 \pm 2.8^{\mathrm{f}}\end{array}$ & 31.7 \\
\hline
\end{tabular}

\footnotetext{
a Troposphere (T) and stratosphere (S) values given separately, wherever possible. All CTM results are for 2009.

b Review by Holmes et al. (2011).

c Fry et al. (2012).

d Forster et al. (2007).

e $15 \%$ of $\mathrm{CH}_{4}$ direct $\mathrm{RF}$, Myhre et al. (2007).

${ }^{f}$ Boucher (2012), excluding $\mathrm{CO}_{2}$ production.
}

upper troposphere. Stratospheric ozone increases twice as much as tropospheric ozone (10.4 DU ppm $\left.\left(\mathrm{CH}_{4}\right)^{-1}\right)$, but the change is small compared to the total stratospheric column. We find that stratospheric water vapor produced by oxidation of methane causes small decreases in stratospheric ozone (-4.3 DU ppm $\left.\left(\mathrm{CH}_{4}\right)^{-1}\right)$. Although these stratospheric effects have greater uncertainty because they are assessed from a single model, the stratospheric chemistry mechanism in Oslo CTM3 is able to reproduce recent stratospheric ozone variability (Isaksen et al., 2012).

Ozone generally has greater radiative forcing efficiency in the troposphere than in the stratosphere (Forster and Shine, 1997), so tropospheric ozone changes tend to dominate the ozone RF components. In our 3 models, the methane $\mathrm{RF}$ through tropospheric ozone is $30-50 \%$ of the direct methane RF. After including stratospheric changes, ozone contributes up to $65 \%$ of the direct RF. Previous IPCC assessments have assumed $25 \%$ for purposes of calculating GWP (Shine et al., 1995; Forster et al., 2007), similar to a recent estimate of $21 \%$ based on tropospheric changes alone (Fry et al., 2012). Methane perturbation data from the TAR (3.67 DU $\left(\mathrm{O}_{3}\right) \operatorname{ppm}\left(\mathrm{CH}_{4}\right)^{-1}$ ) (Prather et al., 2001), however, suggest that tropospheric ozone RF is about $40 \%$ of the methane RF $\left(154 \mathrm{~mW} \mathrm{~m}^{-2} \mathrm{ppm}\left(\mathrm{CH}_{4}\right)^{-1}\right.$, assuming efficiency of $42 \mathrm{~mW} \mathrm{~m}^{-2} \mathrm{DU}\left(\mathrm{O}_{3}\right)^{-1}$ ) (Ramaswamy et al., 2001).
Accounting for both direct and indirect effects, the methane RF efficiency, $F_{\mathrm{e}}$, is $620 \mathrm{~mW} \mathrm{~m}^{-2} \mathrm{ppm}\left(\mathrm{CH}_{4}\right)^{-1}$ in steady-state. A $1 \mathrm{Tg}$ pulse emission of methane raises the atmospheric abundance by $\delta=0.364 \mathrm{ppb}$, which decays at a rate $f \tau_{\mathrm{CH}_{4}}$, where $f=1.34$ is the methane feedback on its lifetime. We use $\tau_{\mathrm{CH}_{4}}=9.14 \mathrm{yr}$ (Prather et al., 2012). Neglecting delays between emission time and stratospheric impacts, the 100 -yr absolute GWP is $\delta f \tau_{\mathrm{CH}_{4}} F_{\mathrm{e}}=$ $2.76 \mathrm{~mW} \mathrm{yr} \mathrm{m}^{-2}$, compared to $0.087 \mathrm{~mW} \mathrm{yr} \mathrm{m}^{-2}$ for $\mathrm{CO}_{2}$. Thus, the methane $\mathrm{GWP}_{100}$ is 31.8 . Our result is higher than several previous reports, generally near 25 (Forster et al., 2007; Fry et al., 2012), mainly because we include stratospheric ozone effects, but also because the updated and longer methane lifetime used here (Prather et al., 2012). IPCC TAR recommended $f=1.4$ (Prather et al., 2001), which would imply an even larger GWP, but since $f$ depends on $\tau_{\mathrm{CH}_{4}}$ the two must be chosen consistently. Uncertainty in the GWP is difficult to assess without further modeling and analysis of stratospheric impacts, but it is likely $\pm 20 \%$ or larger.

\section{Conclusions}

Over 1997-2009, the three CTMs in this work exhibit common variability in methane lifetime, which is also shared by other published model studies. The simulated $\tau_{\mathrm{CH}_{4} \times \mathrm{OH}}$ anomalies generally lie within the constraints provided by 
global methyl chloroform observations, but correlate poorly with year-to-year changes inferred from the NOAA and AGAGE networks. However, while both networks provide strong and mutually consistent estimates of the long-term mean $\tau_{\mathrm{CH}_{4} \times \mathrm{OH}}$, their year-to-year anomalies differ from each other by as much as they differ from the CTMs. These differences in global $\tau_{\mathrm{CH}_{4} \times \mathrm{OH}}$ anomalies between networks can partially be explained by small discrepancies $(\sim 0.1 \mathrm{ppt})$ in the monthly mean methyl chloroform concentrations at collocated measurement sites.

We quantitatively explain $\tau_{\mathrm{CH}_{4} \times \mathrm{OH}}$ variability in the CTMs with 5 climate and emission variables: air temperature, water vapor, ozone column, biomass burning emissions, and lightning $\mathrm{NO}_{\mathrm{x}}$ emissions. A parametric model built on these 5 factors reproduces $90 \%$ of the variability in methane lifetime during 1997-2009. For projections over many decades, the parametric model also includes 5 factors for anthropogenic emissions and one for methane feedback. The ensemble of 3 models provides a measure of uncertainty in each parametric factor, which we use to project past and future methane and its lifetime, with uncertainties. While this approach lacks the full complexity of atmospheric chemistry that can be included through multi-decadal simulations of a CTM or GCM, the advantage is that it can be rapidly applied to many climate data sets or socioeconomic scenarios.

Using the parametric model to reconstruct methane lifetime for 1980-2005, we estimate $2.2 \pm 1.8 \%$ decrease in $\tau_{\mathrm{CH}_{4} \times \mathrm{OH}}$, in contrast to previous parametric approaches that suggested increases or no change. Our decrease is the same direction of change as previous CTM studies and consistent with methyl chloroform observations, but smaller in magnitude than many past estimates. The parametric model may underestimate the trend because it does not consider the location of anthropogenic emissions. We also use the parametric model to project future methane abundance, which implicitly assumes that the emission and climate processes that controlled methane lifetime in the recent past will remain dominant throughout the 21 st century. For the RCP 8.5 scenario, our projected methane abundances are larger than the CMIP5 recommendations, which are based on the MAGICC model, but the uncertainty encompasses the difference. Our projected change in methane lifetime is consistent with an ensemble of GCMs containing atmospheric chemistry, providing further evidence that the parametric model includes the key processes. Uncertainty in 2100 methane abundance is $10 \%$ based on the processes we have assessed here, which include a simple treatment of natural methane emissions. Water vapor, anthropogenic $\mathrm{NO}_{\mathrm{x}}$ emissions, and methane feedback on its $\mathrm{OH}$ sink are the major drivers of $\tau_{\mathrm{CH}_{4} \times \mathrm{OH}}$ in both the historical reconstruction and future RCP 8.5 scenario.

We also provide a new estimate of the indirect components of methane RF. Based on three CTMs, tropospheric ozone contributes $30-50 \%$ of the direct methane RF, compared to $25 \%$ that has been used in previous IPCC assessments (Forster et al., 2007). Using one model with strato- spheric chemistry (Oslo CTM3), we calculate the stratospheric chemical effects of methane, including those mediated by water vapor. Combining the troposphere and stratosphere results, the total methane-induced ozone RF is $50 \%$ of the direct methane RF. Based on these data, the 100-yr methane GWP is 32 , which is higher than several previous estimates around 25 .

\section{Supplementary material related to this article is available online at: http://www.atmos-chem-phys.net/13/ 285/2013/acp-13-285-2013-supplement.pdf.}

Acknowledgements. Mingquan Mu (UC Irvine) provided GEOSChem data that we compare to our simulations. This research was supported by the NASA Modeling, Analysis, and Prediction Program (NNX09AJ47G), the Office of Science (BER) of the US Department of Energy (DE-SC0007021), and the Kavli Chair in Earth System Science.

Edited by: B. N. Duncan

\section{References}

Austin, J. and Scinocca, J.: Long-term projections of stratospheric ozone, in SPARC Report on the Evaluation of ChemistryClimate Models, SPARC Report No. 5, WCRP-132, WMO/TD No. 40, edited by: Eyring, V., Shepherd, T. G., and Waugh, D. W., WMO, available at: http://www.sparc-climate.org/publications/ sparc-reports/sparc-report-no5/, 2010.

Bian, H., Prather, M., and Takemura, T.: Tropospheric aerosol impacts on trace gas budgets through photolysis, J. Geophys. Res.Atmos., 108, 4242, doi:10.1029/2002JD002743, 2003.

Bosilovich, M. G., Robertson, F. R., and Chen, J.: Global energy and water budgets in MERRA, J. Climate, 24, 5721-5739, doi:10.1175/2011JCLI4175.1, 2011.

Boucher, O.: Comparison of physically and economically based $\mathrm{CO}_{2}$-equivalences for methane, Earth Syst. Dynam., 3, 49-61, doi:10.5194/esd-3-49-2012, 2012.

Bousquet, P., Hauglustaine, D., Peylin, P., Carouge, C., and Ciais, P.: Two decades of $\mathrm{OH}$ variability as inferred by an inversion of atmospheric transport and chemistry of methyl chloroform, Atmos. Chem. Phys., 5, 2635-2656, doi:10.5194/acp-52635-2005, 2005.

Carver, G., Brown, P., and Wild, O.: The ASAD atmospheric chemistry integration package and chemical reaction database, Comput. Phys. Commun., 105, 197-215, 1997.

Chen, G., Huey, L., Trainer, M., Nicks, D., Corbett, J., Ryerson, T., Parrish, D., Neuman, J., Nowak, J., Tanner, D., Holloway, J., Brock, C., Crawford, J., Olson, J., Sullivan, A., Weber, R., Schauffler, S., Donnelly, S., Atlas, E., Roberts, J., Flocke, F., Hubler, G., and Fehsenfeld, F.: An investigation of the chemistry of ship emission plumes during ITCT 2002, J. Geophys. Res.Atmos., 110, D10S90, doi:10.1029/2004JD005236, 2005.

Christian, H., Blakeslee, R., Boccippio, D., Boeck, W., Buechler, D., Driscoll, K., Goodman, S., Hall, J., Koshak, W., Mach, D., and Stewart, M.: Global frequency and distribution of lightning 
as observed from space by the Optical Transient Detector, J. Geophys. Res.-Atmos., 108, 4005, doi:10.1029/2002JD002347, 2003.

Collins, M., An, S.-I., Cai, W., Ganachaud, A., Guilyardi, E., Jin, F.-F., Jochum, M., Lengaigne, M., Power, S., Timmermann, A., Vecchi, G., and Wittenberg, A: The impact of global warming on the tropical Pacific Ocean and El Niño, Nat. Geosci. 3, 391-397, doi:10.1038/NGEO868, 2010.

Dalsoren, S. B. and Isaksen, I.: CTM study of changes in tropospheric hydroxyl distribution 1990-2001 and its impact on methane, Geophys. Res. Lett., 33, L23811, doi:10.1029/2006GL027295, 2006.

Dalsoren, S. B., Eide, M. S., Myhre, G., Endresen, O., Isaksen, I. S. A., and Fuglestvedt, J. S.: Impacts of the large increase in international ship traffic 2000-2007 on tropospheric ozone and methane, Environ. Sci. Technol., 44, 2482-2489, doi:10.1021/es902628e, 2010.

Del Genio, A. D., Yao, M.-S. and Jonas, J.: Will moist convection be stronger in a warmer climate? Geophys. Res. Lett., 34, L16703, doi:10.1029/2007GL030525, 2007.

Dentener, F., Peters, W., Krol, M., van Weele, M., Bergamaschi, P., and Lelieveld, J.: Interannual variability and trend of $\mathrm{CH}_{4}$ lifetime as a measure for $\mathrm{OH}$ changes in the 1979-1993 time period, J. Geophys. Res.-Atmos., 108, 4442, doi:10.1029/2002JD002916, 2003.

Dlugokencky, E. J., Nisbet, E. G., Fisher, R., and Lowry, D.: Global atmospheric methane: budget, changes and dangers, Philos. T. R. Soc. A, 369, 2058-2072, doi:10.1098/rsta.2010.0341, 2011.

Duncan, B., Portman, D., Bey, I., and Spivakovsky, C.: Parameterization of $\mathrm{OH}$ for efficient computation in chemical tracer models, J. Geophys. Res.-Atmos., 105, 12259-12262, 2000.

Duncan, B. N., Bey, I., Chin, M., Mickley, L. J., Fairlie, T. D., Martin, R. V., and Matsueda, H.: Indonesian wildfires of 1997: Impact on tropospheric chemistry, J. Geophys. Res.-Atmos., 108, 4458, doi:10.1029/2002JD003195, 2003.

Eyring, V., Cionni, I., Lamarque, J. F., Akiyoshi, H., Bodeker, G. E., Charlton-Perez, A. J., Frith, S. M., Gettelman, A., Kinnison, D. E., Nakamura, T., Oman, L. D., Pawson, S., and Yamashita, Y.: Sensitivity of 21 st century stratospheric ozone to greenhouse gas scenarios, Geophys. Res. Lett., 37, L16807, doi:10.1029/2010GL044443, 2010a.

Eyring, V., Isaksen, I. S. A., Berntsen, T., Collins, W. J., Corbett, J. J., Endresen, O., Grainger, R. G., Moldanova, J., Schlager, H., and Stevenson, D. S.: Transport impacts on atmosphere and climate: shipping, Atmos. Environ., 44, 4735-4771, doi:10.1016/j.atmosenv.2009.04.059, 2010b.

Fiore, A. M., Horowitz, L. W., Dlugokencky, E. J., and West, J. J.: Impact of meteorology and emissions on methane trends, 1990-2004, Geophys. Res. Lett., 33, L12809, doi:10.1029/2006GL026199, 2006.

Fiore, A. M., Dentener, F. J., Wild, O., Cuvelier, C., Schultz, M. G., Hess, P., Textor, C., Schulz, M., Doherty, R. M., Horowitz, L. W., MacKenzie, I. A., Sanderson, M. G., Shindell, D. T., Stevenson, D. S., Szopa, S., Van Dingenen, R., Zeng, G., Atherton, C., Bergmann, D., Bey, I., Carmichael, G., Collins, W. J., Duncan, B. N., Faluvegi, G., Folberth, G., Gauss, M., Gong, S., Hauglustaine, D., Holloway, T., Isaksen, I. S. A., Jacob, D. J., Jonson, J. E., Kaminski, J. W., Keating, T. J., Lupu, A., Marmer, E., Montanaro, V., Park, R. J., Pitari, G., Pringle, K. J., Pyle, J. A.,
Schroeder, S., Vivanco, M. G., Wind, P., Wojcik, G., Wu, S., and Zuber, A: Multimodel estimates of intercontinental sourcereceptor relationships for ozone pollution, J. Geophys. Res.Atmos., 114, D04301, doi:10.1029/2008JD010816, 2009.

Forster, P. and Shine, K. P.: Radiative forcing and temperature trends from stratospheric ozone changes, J. Geophys. Res.Atmos., 102, 10841-10855, 1997.

Forster, P., Ramaswamy, V., Artaxo, P., Berntsen, T., Betts, R., Fahey, D. W., Haywood, J., Lean, J., Lowe, D., Myhre, G., Nganga, J., Prinn, R., Raga, G., Schulz, M., and Van Dorland, R.: Changes in Atmospheric Constituents and in Radiative Forcing, in Climate Change 2007: The Physical Science Basis. Contribution of Working Group I to the Fourth Assessment Report of the Intergovernmental Panel on Climate Change, edited by: Solomon, S., Qin, D., Manning, M., Chen, Z., Marquis, M., Averyt, K., Tignor, M., and Miller, H., Cambridge University Press, Cambridge, 2007.

Fry, M. M., Naik, V., West, J. J., Schwarzkopf, M. D., Fiore, A. M., Collins, W. J., Dentener, F. J., Shindell, D. T., Atherton, C., Bergmann, D., Duncan, B. N., Hess, P., MacKenzie, I. A., Marmer, E., Schultz, M. G., Szopa, S., Wild, O., and Zeng, G.: The influence of ozone precursor emissions from four world regions on tropospheric composition and radiative climate forcing, J. Geophys. Res.-Atmos., 117, D07306, doi:10.1029/2011JD017134, 2012.

Fuglestvedt, J., Berntsen, T., Isaksen, I., Mao, H., Liang, X., and Wang, W.: Climatic forcing of nitrogen oxides through changes in tropospheric ozone and methane; global 3-D model studies, Atmos. Environ., 33, 961-977, 1999.

Granier, C., Bessagnet, B., Bond, T., D’Angiola, A., van der Gon, H. D., Frost, G. J., Heil, A., Kaiser, J. W., Kinne, S., Klimont, Z., Kloster, S., Lamarque, J.-F., Liousse, C., Masui, T., Meleux, F., Mieville, A., Ohara, T., Raut, J.-C., Riahi, K., Schultz, M. G., Smith, S. J., Thompson, A., van Aardenne, J., van der Werf, G. R., and van Vuuren, D. P.: Evolution of anthropogenic and biomass burning emissions of air pollutants at global and regional scales during the 1980-2010 period, Climatic Change, 109, 163-190, doi:10.1007/s10584-011-0154-1, 2011.

Guenther, A., Karl, T., Harley, P., Wiedinmyer, C., Palmer, P. I., and Geron, C.: Estimates of global terrestrial isoprene emissions using MEGAN (Model of Emissions of Gases and Aerosols from Nature), Atmos. Chem. Phys., 6, 3181-3210, 2006, http://www.atmos-chem-phys.net/6/3181/2006/.

Held, I. M. and Soden, B. J.: Robust responses of the hydrological cycle to global warming, J. Climate, 19, 5686-5699, 2006.

Hess, P. and Mahowald, N.: Interannual variability in hindcasts of atmospheric chemistry: the role of meteorology, Atmos. Chem. Phys., 9, 5261-5280, doi:10.5194/acp-9-5261-2009, 2009.

Holmes, C. D., Tang, Q., and Prather, M. J.: Uncertainties in climate assessment for the case of aviation NO, P. Natl. Acad. Sci. USA, 108, 10997-11002, doi:10.1073/pnas.1101458108, 2011.

Hoor, P., Borken-Kleefeld, J., Caro, D., Dessens, O., Endresen, O., Gauss, M., Grewe, V., Hauglustaine, D., Isaksen, I. S. A., Jöckel, P., Lelieveld, J., Myhre, G., Meijer, E., Olivie, D., Prather, M., Schnadt Poberaj, C., Shine, K. P., Staehelin, J., Tang, Q., van Aardenne, J., van Velthoven, P., and Sausen, R.: The impact of traffic emissions on atmospheric ozone and $\mathrm{OH}$ : results from QUANTIFY, Atmos. Chem. Phys., 9, 3113-3136, doi:10.5194/acp-9-3113-2009, 2009. 
Houweling, S., Dentener, F., and Lelieveld, J.: Simulation of preindustrial atmospheric methane to constrain the global source strength of natural wetlands, J. Geophys. Res., 105, 1724317255, doi:10.1029/2000JD900193, 2000.

Hsu, J. and Prather, M. J.: Stratospheric variability and tropospheric ozone, J. Geophys. Res.-Atmos., 114, D06102, doi:10.1029/2008JD010942, 2009.

IPCC: Climate Change 2007: The Physical Science Basis. Contribution of Working Group I to the Fourth Assessment Report of the Intergovernmental Panel on Climate Change, edited by: Solomon, S., Qin, D., Manning, M., Chen, Z., Marquis, M., Averyt, K., Tignor, M., and Miller, H., Cambridge University Press, Cambridge, UK, 2007.

Isaksen, I., Zerefos, C., Kourtidis, K., Meleti, C., Dalsoren, S., Sundet, J., Grini, A., Zanis, P., and Balis, D.: Tropospheric ozone changes at unpolluted and semipolluted regions induced by stratospheric ozone changes, J. Geophys. Res.-Atmos., 110, D02302, doi:10.1029/2004JD004618, 2005.

Isaksen, I. S. A., Zerefos, C., Wang, W.-C., Balis, D., Eleftheratos, K., Rognerud, B., Stordal, F., Berntsen, T. K., LaCasce, J. H., Søvde, O. A., Olivie, D., Orsolini, J., Zyrichidou, I., Prather, M., and Tuinder, O. N. E.: Attribution of the Arctic ozone column deficit in March 2011, Geophys. Res. Lett., 39, L24810, doi:10.1029/2012GL053876, 2012.

Jacob, D., Field, B., Jin, E., Bey, I., Li, Q., Logan, J., and Yantosca, R.: Atmospheric budget of acetone, J. Geophys. Res., 107, 4100, doi:10.1029/2001JD000694, 2002.

John, J. G., Fiore, A. M., Naik, V., Horowitz, L. W., and Dunne, J. P.: Climate versus emission drivers of methane lifetime against loss by tropospheric OH from 1860-2100, Atmos. Chem. Phys., 12, 12021-12036, doi:doi:10.5194/acp-12-12021-2012, 2012.

Karlsdottir, S. and Isaksen, I.: Changing methane lifetime: possible cause for reduced growth, Geophys. Res. Lett., 27, 93-96, 2000.

Krol, M. and Lelieveld, J.: Can the variability in tropospheric $\mathrm{OH}$ be deduced from measurements of 1,1,1-trichloroethane (methyl chloroform)? J. Geophys. Res.-Atmos., 108, 4125, doi:10.1029/2002JD002423, 2003.

Krol, M. and van Weele, M.: Implications of variations in photodissociation rates for global tropospheric chemistry, Atmos. Environ., 31, 1257-1273, 1997.

Labrador, L. J., von Kuhlmann, R., and Lawrence, M. G.: Strong sensitivity of the global mean $\mathrm{OH}$ concentration and the tropospheric oxidizing efficiency to the source of NOx from lightning, Geophys. Res. Lett. 31, L06102, doi:10.1029/2003GL019229, 2004.

Lamarque, J.-F., Bond, T. C., Eyring, V., Granier, C., Heil, A., Klimont, Z., Lee, D., Liousse, C., Mieville, A., Owen, B., Schultz, M. G., Shindell, D., Smith, S. J., Stehfest, E., van Aardenne, J., Cooper, O. R., Kainuma, M., Mahowald, N., McConnell, J. R., Naik, V., Riahi, K., and van Vuuren, D. P.: Historical (1850-2000) gridded anthropogenic and biomass burning emissions of reactive gases and aerosols: methodology and application, Atmos. Chem. Phys., 10, 7017-7039, doi:10.5194/acp10-7017-2010, 2010.

Lamarque, J.-F., Shindell, D., Josse, B., Eyring, V., Young, P. J., Cionni, I., Bergmann, D., Cameron-Smith, P., Collins, W. J., Doherty, R., Dalsoren, S. B., Faluvegi, G., Folberth, G., Ghan, S. J., Horowitz, L. W., Lee, Y., McKenzie, I., Nagashima, T., Naik, V., Plummer, D., Rumbold, S., Skeie, R., Stevenson, D.
S., Strode, S., Sudo, K., Szopa, S., Voulgarakis, A., and Zeng, G.: The Atmospheric Chemistry and Climate Model Intercomparison Project (ACCMIP): Overview and description of models, simulations and climate diagnostics, Geosci. Model Dev. Discuss., in review, 2012.

Lawrence, M. G. and Salzmann, M.: On interpreting studies of tracer transport by deep cumulus convection and its effects on atmospheric chemistry, Atmos. Chem. Phys., 8, 6037-6050, doi:10.5194/acp-8-6037-2008, 2008.

Lee, D. S., Pitari, G., Grewe, V., Gierens, K., Penner, J. E., Petzold, A., Prather, M. J., Schumann, U., Bais, A., Berntsen, T., Iachetti, D., Lim, L. L., and Sausen, R.: Transport impacts on atmosphere and climate: aviation, Atmos. Environ., 44, 46784734, doi:10.1016/j.atmosenv.2009.06.005, 2010.

Lelieveld, J. and Crutzen, P.: Role of deep cloud convection in the ozone budget of the troposphere, Science, 264, 1759-1761, 1994.

Macintyre, H. L. and Evans, M. J.: Sensitivity of a global model to the uptake of $\mathrm{N}_{2} \mathrm{O}_{5}$ by tropospheric aerosol, Atmos. Chem. Phys., 10, 7409-7414, doi:10.5194/acp-10-7409-2010, 2010.

Manning, M. R., Lowe, D. C., Moss, R. C., Bodeker, G. E. and Allan, W.: Short-term variations in the oxidizing power of the atmosphere, Nature, 436, 1001-1004, doi:10.1038/nature03900, 2005.

Mao, J., Jacob, D. J., Evans, M. J., Olson, J. R., Ren, X., Brune, W. H., St Clair, J. M., Crounse, J. D., Spencer, K. M., Beaver, M. R., Wennberg, P. O., Cubison, M. J., Jimenez, J. L., Fried, A., Weibring, P., Walega, J. G., Hall, S. R., Weinheimer, A. J., Cohen, R. C., Chen, G., Crawford, J. H., McNaughton, C., Clarke, A. D., Jaegle, L., Fisher, J. A., Yantosca, R. M., Le Sager, P., and Carouge, C.: Chemistry of hydrogen oxide radicals $\left(\mathrm{HO}_{\mathrm{x}}\right)$ in the Arctic troposphere in spring, Atmos. Chem. Phys., 10, 5823-5838, doi:10.5194/acp-10-5823-2010, 2010.

Martin, R., Jacob, D., Yantosca, R., Chin, M., and Ginoux, P.: Global and regional decreases in tropospheric oxidants from photochemical effects of aerosols, J. Geophys. Res.-Atmos., 108, 4097, doi:10.1029/2002JD002622, 2003.

McCulloch, A., Aucott, M., Graedel, T., Kleiman, G., Midgley, P., and Li, Y.: Industrial emissions of trichloroethene, tetrachloroethene, and dichloromethane: reactive chlorine emissions inventory, J. Geophys. Res.-Atmos., 104, 8417-8427, 1999.

Meinshausen, M., Raper, S. C. B., and Wigley, T. M. L.: Emulating coupled atmosphere-ocean and carbon cycle models with a simpler model, MAGICC6-Part 1: Model description and calibration, Atmos. Chem. Phys., 11, 1417-1456, doi:10.5194/acp-111417-2011, 2011a.

Meinshausen, M., Smith, S. J., Calvin, K., Daniel, J. S., Kainuma, M. L. T., Lamarque, J. F., Matsumoto, K., Montzka, S. A., Raper, S. C. B., Riahi, K., Thomson, A., Velders, G. J. M., and van Vuuren, D. P. P.: The RCP greenhouse gas concentrations and their extensions from 1765 to 2300 , Clim. Change, 109, 213-241, doi:10.1007/s10584-011-0156-z, $2011 \mathrm{~b}$.

Millet, D. B., Guenther, A., Siegel, D. A., Nelson, N. B., Singh, H. B., de Gouw, J. A., Warneke, C., Williams, J., Eerdekens, G., Sinha, V., Karl, T., Flocke, F., Apel, E., Riemer, D. D., Palmer, P. I., and Barkley, M.: Global atmospheric budget of acetaldehyde: 3-D model analysis and constraints from in-situ and satellite observations, Atmos. Chem. Phys., 10, 3405-3425, doi:10.5194/acp-10-3405-2010, 2010. 
Montzka, S., Spivakovsky, C., Butler, J., Elkins, J., Lock, L., and Mondeel, D.: New observational constraints for atmospheric hydroxyl on global and hemispheric scales, Science, 288, 500-503, 2000

Montzka, S. A., Krol, M., Dlugokencky, E., Hall, B., Joeckel, P., and Lelieveld, J.: Small Interannual Variability of Global Atmospheric Hydroxyl, Science, 331, 67-69, doi:10.1126/science.1197640, 2011.

Murray, L. T., Jacob, D. J., Logan, J. A., Hudman, R. C., and Koshak, W. J.: Optimized regional and interannual variability of lightning in a global chemical transport model constrained by LIS/OTD satellite data, J. Geophys. Res.-Atmos., 117, D20307, doi:10.1029/2012JD017934, 2012.

Myhre, G., Nilsen, J. S., Gulstad, L., Shine, K. P., Rognerud, B., and Isaksen, I. S. A.: Radiative forcing due to stratospheric water vapour from $\mathrm{CH}_{4}$ oxidation, Geophys. Res. Lett., 34, L01807, doi:10.1029/2006GL027472, 2007.

Myhre, G., Shine, K. P., Raedel, G., Gauss, M., Isaksen, I. S. A., Tang, Q., Prather, M. J., Williams, J. E., van Velthoven, P., Dessens, O., Koffi, B., Szopa, S., Hoor, P., Grewe, V., Borken-Kleefeld, J., Berntsen, T. K., and Fuglestvedt, J. S.: Radiative forcing due to changes in ozone and methane caused by the transport sector, Atmos. Environ., 45, 387-394, doi:10.1016/j.atmosenv.2010.10.001, 2011.

Naik, V., Voulgarakis, A., Fiore, A. M., Lamarque, J. F., Lin, M., Prather, M. J., Young, P. J., Bergmann, D., Cameron-Smith, P. J., Cionni, I., Collins, W. J., Dalsøren, S. B., Doherty, R., Eyring, V., Faluvegi, G., Folberth, G., Horowitz, L., Josse, B., Lee, Y. H., KcKenzie, I. A., Nagashima, T., Plummer, D., Righi, M., Rumbold, S., Skeie, R., Shindell, D. T., Stevenson, D., Strode, S., Sudo, K., Szopa, S., and Zeng, G.: Preindustrial to present day changes in tropospheric hydroxyl radical and methane lifetime from the Atmospheric Chemistry Climate Model Intercomparison Project (ACCMIP), Atmos. Chem. Phys. Discuss., 12, 30755-30804, doi:10.5194/acpd-12-30755-2012, 2012.

Neu, J. L., Prather, M. J., and Penner, J. E.: Global atmospheric chemistry: Integrating over fractional cloud cover, J. Geophys. Res.-Atmos., 112, D11306, doi:10.1029/2006JD008007, 2007.

Newman, P. A., Daniel, J. S., Waugh, D. W., and Nash, E. R.: A new formulation of equivalent effective stratospheric chlorine (EESC), Atmos. Chem. Phys., 7, 4537-4552, doi:10.5194/acp-74537-2007, 2007.

Olson, J., Crawford, J., Chen, G., Brune, W., Faloona, I., Tan, D., Harder, H., and Martinez, M.: A reevaluation of airborne $\mathrm{HO}_{\mathrm{x}}$ observations from NASA field campaigns, J. Geophys. Res.Atmos., 111, D10301, doi:10.1029/2005JD006617, 2006.

Ott, L. E., Pickering, K. E., Stenchikov, G. L., Allen, D. J., DeCaria, A. J., Ridley, B., Lin, R.-F., Lang, S., and Tao, W.K.: Production of lightning $\mathrm{NO}_{\mathrm{x}}$ and its vertical distribution calculated from three-dimensional cloud-scale chemical transport model simulations, J. Geophys. Res.-Atmos., 115, D04301, doi:10.1029/2009JD011880, 2010.

Prather, M.: Numerical advection by conservation of 2nd-order moments, J. Geophys. Res.-Atmos., 91, 6671-6681, 1986.

Prather, M., Ehhalt, D., Dentener, F., Derwent, R., Dlugokencky, E., Holland, E., Isaksen, I., Katima, J., Kirchhoff, V., Matson, P., Midgley, P., and Wang, M.: Atmospheric Chemistry and Greenhouse Gases, in Climate Change 2001: The Scientific Basis. Third Assessment Report of the Intergovernmental Panel on Cli- mate Change, edited by: Houghton, J., Ding, Y., Griggs, D., Noguer, M., van der Linden, P., Dai, X., Maskell, K., and Johnson, C., Cambridge University Press, Cambridge, UK. 2001.

Prather, M. J., Zhua, X., Strahan, S. E., Steenrod, S. D., and Rodriguez, J. M.: Quantifying errors in trace species transport modeling, P. Natl. Acad. Sci. USA, 105, 19617-19621, doi:10.1073/pnas.0806541106, 2008.

Prather, M., Holmes, C., and Hsu, J.: Reactive greenhouse gas scenarios: Systematic exploration of uncertainties and the role of atmospheric chemistry, Geophys. Res. Lett., 39, doi:10.1029/2012GL051440, 2012.

Price, C. and Rind, D.: Modeling global lightning distributions in a general circulation model, Mon. Weather Rev., 122, 19301939, 1994.

Prinn, R., Huang, J., Weiss, R., Cunnold, D., Fraser, P., Simmonds, P., McCulloch, A., Harth, C., Reimann, S., Salameh, P., O’Doherty, S., Wang, R., Porter, L., Miller, B., and Krummel, P.: Evidence for variability of atmospheric hydroxyl radicals over the past quarter century, Geophys. Res. Lett., 32, L07809, doi:10.1029/2004GL022228, 2005.

Ramaswamy, V., Boucher, O., Haigh, J., Hauglustaine, D., Haywood, J., Myhre, G., Nakajima, T., Shi, G. Y., and Solomon, S.: Radiative Forcing of Climate Change, in Cliamte Change 2001: The Scientific Basis. Third Assessment Report of the Intergovernmental Panel on Climate Change, edited by: Houghton, J. T., Ding, Y., Griggs, D., Noguer, M., van der Linden, P. J., Dai, X., Maskell, K., and Johnson, C., Cambridge University Press, Cambridge, UK. 2001

Riahi, K., Grübler, A., and Nakicenovic, N.: Scenarios of long-term socio-economic and environmental development under climate stabilization, Technol. Forecast. Soc., 74, 887-935, 2007.

Rienecker, M. M., Suarez, M. J., Todling, R., Bacmeister, J., Takacs, L., Liu, H.-C., Gu, W., Sienkiewicz, M., Koster, R. D., Gelaro, R., Stajner, I., and Nielsen, J. E.: The GEOS-5 Data Assimilation System, Technical Report Series on Global Modeling and Data Assimilation. 2008.

Rienecker, M. M., Suarez, M. J., Gelaro, R., Todling, R., Bacmeister, J., Liu, E., Bosilovich, M. G., Schubert, S. D., Takacs, L., Kim, G.-K., Bloom, S., Chen, J., Collins, D., Conaty, A., Da Silva, A., Gu, W., Joiner, J., Koster, R. D., Lucchesi, R., Molod, A., Owens, T., Pawson, S., Pegion, P., Redder, C. R., Reichle, R., Robertson, F. R., Ruddick, A. G., Sienkiewicz, M., and Woollen, J.: MERRA: NASA's Modern-Era Retrospective Analysis for Research and Applications, J. Climate, 24, 3624-3648, doi:10.1175/JCLI-D-11-00015.1, 2011.

Sauvage, B., Martin, R. V., van Donkelaar, A., Liu, X., Chance, K., Jaegle, L., Palmer, P. I., Wu, S., and Fu, T. M.: Remote sensed and in situ constraints on processes affecting tropical tropospheric ozone, Atmos. Chem. Phys., 7, 815-838, doi:10.5194/acp-7-8152007, 2007.

Schultz, M. G., Heil, A., Hoelzemann, J. J., Spessa, A., Thonicke, K., Goldammer, J. G., Held, A. C., Pereira, J. M. C., and van het Bolscher, M.: Global wildland fire emissions from 1960 to 2000, Global Biogeochem. Cycles, 22, GB2002, doi:10.1029/2007GB003031, 2008.

Shine, K. P., Fouquart, Y., Ramaswamy, V., Solomon, S., and Srinivasan, J.: Radiative Forcing, in Climate Change 1994: Radiative Forcing of Climate Change and An Evaluation of the IPCC IS92 Emission Scenarios. Reports of Working Groups I and III 
of the Intergovernmental Panel of Climate Change, edited by: Houghton, J., Meira Filho, L., Bruce, J., Lee, H., Callander, B., Haites, E., Harris, N., and Maskell, K., Cambridge University Press, Cambridge, 1995.

Stevenson, D., Doherty, R., Sanderson, M., Johnson, C., Collins, B., and Derwent, D.: Impacts of climate change and variability on tropospheric ozone and its precursors, Faraday Discuss., 130, 41-57, doi:10.1039/b417412g, 2005.

Stolarski, R. S. and Frith, S. M.: Search for evidence of trend slowdown in the long-term TOMS/SBUV total ozone data record: the importance of instrument drift uncertainty, Atmos. Chem. Phys., 6, 4057-4065, doi:10.5194/acp-6-4057-2006, 2006.

Søvde, O. A., Prather, M. J., Isaksen, I. S. A., Berntsen, T. K., Stordal, F., Zhu, X., Holmes, C. D., and Hsu, J.: The chemical transport model Oslo CTM3, Geosci. Model Dev., 5, 1441-1469, doi:doi:10.5194/gmd-5-1441-2012, 2012.

Spivakovsky, C., Logan, J., Montzka, S., Balkanski, Y., ForemanFowler, M., Jones, D., Horowitz, L., Fusco, A., Brenninkmeijer, C., Prather, M., Wofsy, S., and McElroy, M:Three-dimensional climatological distribution of tropospheric $\mathrm{OH}$ : Update and evaluation, J. Geophys. Res.-Atmos., 105, 8931-8980, 2000.

Tang, Q. and Prather, M. J.: Correlating tropospheric column ozone with tropopause folds: the Aura-OMI satellite data, Atmos. Chem. Phys., 10, 9681-9688, doi:10.5194/acp-10-9681-2010, 2010.

Tiedtke, M.: A comprehensive mass flux scheme for cumulus parameterization in large-scale models, Mon. Weather Rev., 117, 1779-1800, 1989.

Trenberth, K. E., Fasullo, J. T., and Mackaro, J.: Atmospheric moisture transports from ocean to land and global energy flows in reanalyses, J. Climate, 24, 4907-4924, doi:10.1175/2011JCLI4171.1, 2011.

van der Werf, G. R., Randerson, J. T., Giglio, L., Collatz, G. J., Mu, M., Kasibhatla, P. S., Morton, D. C., DeFries, R. S., Jin, Y., and van Leeuwen, T. T.: Global fire emissions and the contribution of deforestation, savanna, forest, agricultural, and peat fires (1997-2009), Atmos. Chem. Phys., 10, 11707-11735, doi:10.5194/acp-10-11707-2010, 2010.

van Vuuren, D. P., Edmonds, J., Kainuma, M., Riahi, K., Thomson, A., Hibbard, K., Hurtt, G. C., Kram, T., Krey, V., Lamarque, J.-F., Masui, T., Meinshausen, M., Nakicenovic, N., Smith, S. J., and Rose, S. K.: The representative concentration pathways: an overview, Clim. Change, 109, 5-31, doi:10.1007/s10584-011-0148-z, 2011.
Vinken, G. C. M., Boersma, K. F., Jacob, D. J., and Meijer, E. W.: Accounting for non-linear chemistry of ship plumes in the GEOS-Chem global chemistry transport model, Atmos. Chem. Phys., 11, 11707-11722, doi:10.5194/acp-11-11707-2011, 2011.

Volk, C., Elkins, J., Fahey, D., Dutton, G., Gilligan, J., Loewenstein, M., Podolske, J., Chan, K., and Gunson, M.: Evaluation of source gas lifetimes from stratospheric observations, J. Geophys. Res.-Atmos., 102, 25543-25564, 1997.

Voulgarakis, A., Savage, N. H., Wild, O., Braesicke, P., Young, P. J., Carver, G. D., and Pyle, J. A.: Interannual variability of tropospheric composition: the influence of changes in emissions, meteorology and clouds, Atmos. Chem. Phys., 10, 2491-2506, doi:10.5194/acp-10-2491-2010, 2010.

Voulgarakis, A., Naik, V., Lamarque, J.-F., Shindell, D. T., Prather, M. J., Wild, O., Young, P. J., Bergmann, D., CameronSmith, P., Cionni, I., Collins, W. J., Dalsøren, S. B., Doherty, R., Field, R. D., Eyring, V., Folberth, G., Horowitz, L., Josse, B., McKenzie, I., Nagashima, T., Plummer, D., Righi, M., Rumbold, S., Skeie, R., Stevenson, D., Strode, S., Sudo, K., Szopa, S., and Zeng, G.: Multimodel simulations of present-day and future $\mathrm{OH}$ and methane lifetime, Atmos. Chem. Phys. Discuss., 12, 2294523005, doi:10.5194/acpd-12-22945-2012, 2012.

Voulgarakis, A., Wild, O., Savage, N. H., Carver, G. D., and Pyle, J. A.: Clouds, photolysis and regional tropospheric ozone budgets, Atmos. Chem. Phys., 9, 8235-8346, doi:10.5194/acp-9-82352009, 2009.

Wang, J. S., McElroy, M. B., Logan, J. A., Palmer, P. I., Chameides, W. L., Wang, Y., and Megretskaia, I. A.: A quantitative assessment of uncertainties affecting estimates of global mean $\mathrm{OH}$ derived from methyl chloroform observations, J. Geophys. Res.Atmos., 113, D12302, doi:10.1029/2007JD008496, 2008.

Wennberg, P., Peacock, S., Randerson, J., and Bleck, R.: Recent changes in the air-sea gas exchange of methyl chloroform, Geophys. Res. Lett., 31, L16112, doi:10.1029/2004GL020476, 2004.

Wu, S., Mickley, L. J., Jacob, D. J., Rind, D., and Streets, D. G.: Effects of 2000-2050 changes in climate and emissions on global tropospheric ozone and the policy-relevant background surface ozone in the United States, J. Geophys. Res.-Atmos., 113, D18312, doi:10.1029/2007JD009639, 2008. 